\title{
DEATHS IN CHILDBED FROM THE EIGHTEENTH CENTURY TO 1935
}

by

IRVINE LOUDON*

'A deep, dark and continuous stream of mortality.'+

INTRODUCTION

This paper is concerned solely with maternal mortality and not with maternal morbidity, neonatal mortality, or the stillbirth rate. Maternal morbidity is expressed as the number of deaths per 1,000 births. "Births" meant "live births" until stillbirth registration was introduced in 1927; thereafter, it meant "total births", i.e. live + still births.

Maternal deaths were traditionally divided into two main groups: (1) associated deaths; (2) puerperal deaths. (They are now known as "indirect" and "direct" obstetric deaths.) (1) Associated deaths were deaths from some incidental illness (for example, phthisis, typhoid, or pneumonia) during pregnancy or the lying-in period. Associated deaths were included in most accounts of maternal deaths before death registration (1838) and in many private reports even in the second half of the nineteenth century. They were also included, at least partially, in some of the early reports of the Registrar General up to 1864. (2) Puerperal deaths were divided into two main groups. (A) Puerperal fever or puerperal sepsis - sometimes described as "metria" or "puerperal pyaemia" in the eighteenth and nineteenth centuries. (B) Accidents of childbirth, which consisted of all other puerperal causes of death. Deaths from haemorrhage (ante- or post-natal) and toxaemia (pre-eclampsia and eclampsia) were the two main groups.

Maternal deaths are deaths occurring in pregnancy, labour, or the lying-in period. The latter was not clearly defined before the mid-nineteenth century and some late deaths were included in early reports. Then it became the convention that the lying-in period was one month from birth: today, for registration purposes, it is six weeks.

For the purpose of this paper, factors which affected the level of maternal mortality are divided broadly into two groups. (1) Clinical factors which include every aspect of obstetric knowledge, education, care (including availability of care provided by midwives and medical practitioners). (2) Social and economic factors operating through their effect on the health of the mother.

*Irvine Loudon, DM, FRCGP, Wellcome Unit for the History of Medicine, 45-47 Banbury Road, Oxford OX2 6PE.

+William Farr in 39th report of the Registrar General for 1876, 1878, p. 242. 
THE MATERNAL MORTALITY RATE: AN ANOMALOUS STATISTIC

An examination of the maternal mortality rate from the mid-nineteenth century until 1935 leads to an unexpected conclusion. It is that the risk of a mother dying in childbirth, especially if she lived in the north of Britain rather than the south, remained substantially the same from 1850 , and possibly from the early nineteenth century, until 1935. The maternal mortality remained undiminished in spite of changes in medical care and standards of living during this period. The main purpose of this paper is to examine the implications of this finding.

Today, maternal deaths are so rare that risk in obstetrics and standards of care are assessed by reference to the perinatal mortality rate. ${ }^{1}$ Until the $1930 \mathrm{~s}$, however, the maternal mortality rate was the dominant statistic. The mean rate for the quinquennium $1856-60$ was 4.6 per 1,000 births and it was the same not only for 1896-1900 but also for 1930-34. Between the mid-nineteenth century and the mid-1930s, the rate remained generally between four and five deaths per 1,000 births in England and Wales, although there were large regional variations (table 1 and fig. 1). In Scotland between 1850 and 1930, the rate was higher because associated deaths were included. There, the maternal mortality remained level for the first fifty years, but it actually increased from 1900 to 1930 from just under five per 1,000 births to well over six by 1930 . This rise occurred within the category "accidents of childbirth"' (see fig. 5, p. 30).

The anxiety created by the absence of any improvement in maternal mortality is apparent in a memorable series of reports by William Farr published as letters to the Registrar General in the Registrar General's Reports. In 1875, Farr was moved to ask, "How long is this sacrifice of lives to go on?", and it was he who was chiefly responsible for presenting the facts of maternal mortality to the public and the medical profession not as an unfortunate and unavoidable fact of life, but as a growing scandal. ${ }^{3}$ Farr's reports were followed by a long series of publications on maternal mortality, which included those by Williams in 1895-96 and 1904, Cullingworth in 1898, Bonney in 1918-19, Janet Campbell (and her colleagues) in 1924, 1932 and 1935, Munro Kerr in 1933, and Douglas and McKinley in 1935, as well as reports from the Ministry of Health and the Medical Research Council in the 1930s.

\footnotetext{
${ }^{1}$ In 1982, the rates for England and Wales were: maternal mortality 11.9 per 100,000 total births (or 0.119 per thousand) and the perinatal mortality rate (= stillbirths and neonatal deaths) was 11.2 per 1,000 total births. On the state of the public health. Report of the Chief Medical Officer, DHSS 1983, London, HMSO. Hereinafter, On the state of the public health, although that title was only used for the second and subsequent reports, not the first.

${ }^{2}$ Within this group the main components of the increase were deaths from toxaemia, hyperemesis, and "other accidents of childbirth". There was no significant increase in deaths from haemorrhage or abortion or from associated diseases except for a brief sharp peak in the latter from influenza in 1918-19 accompanied by a corresponding increase in deaths from abortion at the same time. C.A. Douglas and P.L. McKinley, Report of maternal morbidity and mortality in Scotland, Edinburgh, Department of Health for Scotland, 1935.

${ }^{3}$ William Farr in 38th Report of the Registrar General for 1875, 1877, p.234.

‘W. Williams, 'Puerperal mortality', Trans. Epidemiol. Soc. Lond., 1895-96, 15: 100-133. idem, Deaths in childbed, London, H.K. Lewis, 1904. C.J. Cullingworth, 'On the undiminished mortality from puerperal fever in England and Wales', Trans. Obstet. Soc. Lond., 1898, 39: 91-114. Victor Bonney, 'The continued high mortality of childbearing', Proc. R. Soc. Med., 1918-19, 12(3): 75-107. Janet Campbell,
} 


\section{Deaths in childbed}

TABLE 1. MATERNAL MORTALITY

Deaths per 1000 births: $1847-1980$. England and Wales. Quinquennial rates.

$\begin{array}{cccc}\begin{array}{c}\text { 5-year } \\ \text { period }\end{array} & \begin{array}{c}\text { Puerperal } \\ \text { sepsis }\end{array} & \begin{array}{c}\text { Accidents of } \\ \text { childbirth }\end{array} & \text { Total } \\ (1847-50) & 1 \cdot 9 & 3 \cdot 9 & 5 \cdot 8 \\ 1851-55 & 1 \cdot 5 & 3 \cdot 4 & 4 \cdot 9 \\ 1856-60 & 1 \cdot 5 & 3 \cdot 0 & 4 \cdot 6 \\ 1861-65 & 1 \cdot 6 & 3 \cdot 2 & 4 \cdot 8 \\ 1866-70 & 1 \cdot 5 & 3 \cdot 1 & 4 \cdot 6 \\ 1871-75 & 2 \cdot 4 & 3 \cdot 0 & 5 \cdot 4 \\ 1876-80 & 1 \cdot 7 & 2 \cdot 2 & 3 \cdot 9 \\ 1881-85 & 2 \cdot 8 & 2 \cdot 1 & 4 \cdot 9 \\ 1886-90 & 2 \cdot 4 & 2 \cdot 1 & 4 \cdot 5 \\ 1891-95 & 2 \cdot 5 & 2 \cdot 9 & 5 \cdot 4 \\ 1896-00 & 2 \cdot 0 & 2 \cdot 6 & 4 \cdot 6 \\ 1900-05 & 1 \cdot 9 & 2 \cdot 3 & 4 \cdot 2 \\ 1906-10 & 1 \cdot 6 & 2 \cdot 2 & 3 \cdot 8 \\ 1911-15 & 1 \cdot 5 & 2 \cdot 3 & 3 \cdot 8 \\ 1916-20 & 1 \cdot 5 & 2 \cdot 3 & 3 \cdot 9 \\ 1921-25 & 1 \cdot 5 & 2 \cdot 2 & 3 \cdot 7 \\ 1926-30 & 1 \cdot 8 & 2 \cdot 2 & 4 \cdot 0 \\ 1931-35 & 1 \cdot 6 & 2 \cdot 7 & 4 \cdot 3 \\ 1936-40 & 0 \cdot 77 & 2 \cdot 47 & 3 \cdot 24 \\ 1941-45 & 0 \cdot 36 & 1 \cdot 90 & 2 \cdot 26 \\ 1946-50 & 0 \cdot 14 & 0 \cdot 95 & 1 \cdot 09 \\ 1951-55 & 0 \cdot 098 & 0 \cdot 60 & 0 \cdot 702 \\ 1956-60 & 0 \cdot 06 & 0 \cdot 37 & 0 \cdot 43 \\ 1961-65 & 0 \cdot 04 & 0 \cdot 28 & 0 \cdot 32 \\ 1966-70 & & & 0 \cdot 27 \\ 1971-75 & & & 0 \cdot 13 \\ 1976-80 & & & 0 \cdot 12\end{array}$

Sources: Reports of the Registrar General, and On The state of the public health; reports of the Chief Medical Officer of the Ministry of Health and the Department of Health.

All these reports were concerned with the absence of any significant, let alone sustained, improvement in maternal mortality. ${ }^{5}$ All were also convinced that many of the deaths could have been prevented. ${ }^{6}$ Although there are no national statistics before 1838 , data from a number of sources will be considered here which suggest that a similar level of maternal mortality may have prevailed from the early nineteenth century. If that is the case, there was little alteration in maternal mortality

'Maternal mortality', Reports on public health and medical subjects, No. 25, London Ministry of Health, 1924. idem, Maternity services, London, Faber, 1935. J. Campbell, I. D. Cameron, and D.M. Jones, 'High maternal mortality in certain areas', Reports of public health and medical subjects, No.68 London, Ministry of Health, 1932. J.M. Munro Kerr, Maternal mortality and morbidity, Edinburgh, E. \& S. Livingstone, 1933. Douglas and McKinley, op. cit., note 2 above.

s..... in spite of the general and particular advance of the science and art of medicine in its application to childbirth and in spite of efforts made and arrangements designed to reduce this death rate, the mortality remains, on the whole, unimproved." Interim report of the Departmental Committee on Maternal Mortality and Morbidity, London, Ministry of Health, HMSO, 1932.

B"'The death rate persists at the present unsatisfactory level chiefly because the essential factors prejudicial to betterment are permitted to continue - not because we are ignorant of them but because we have not sufficient determination to remove them." Munro Kerr, op. cit., note 4 above. 


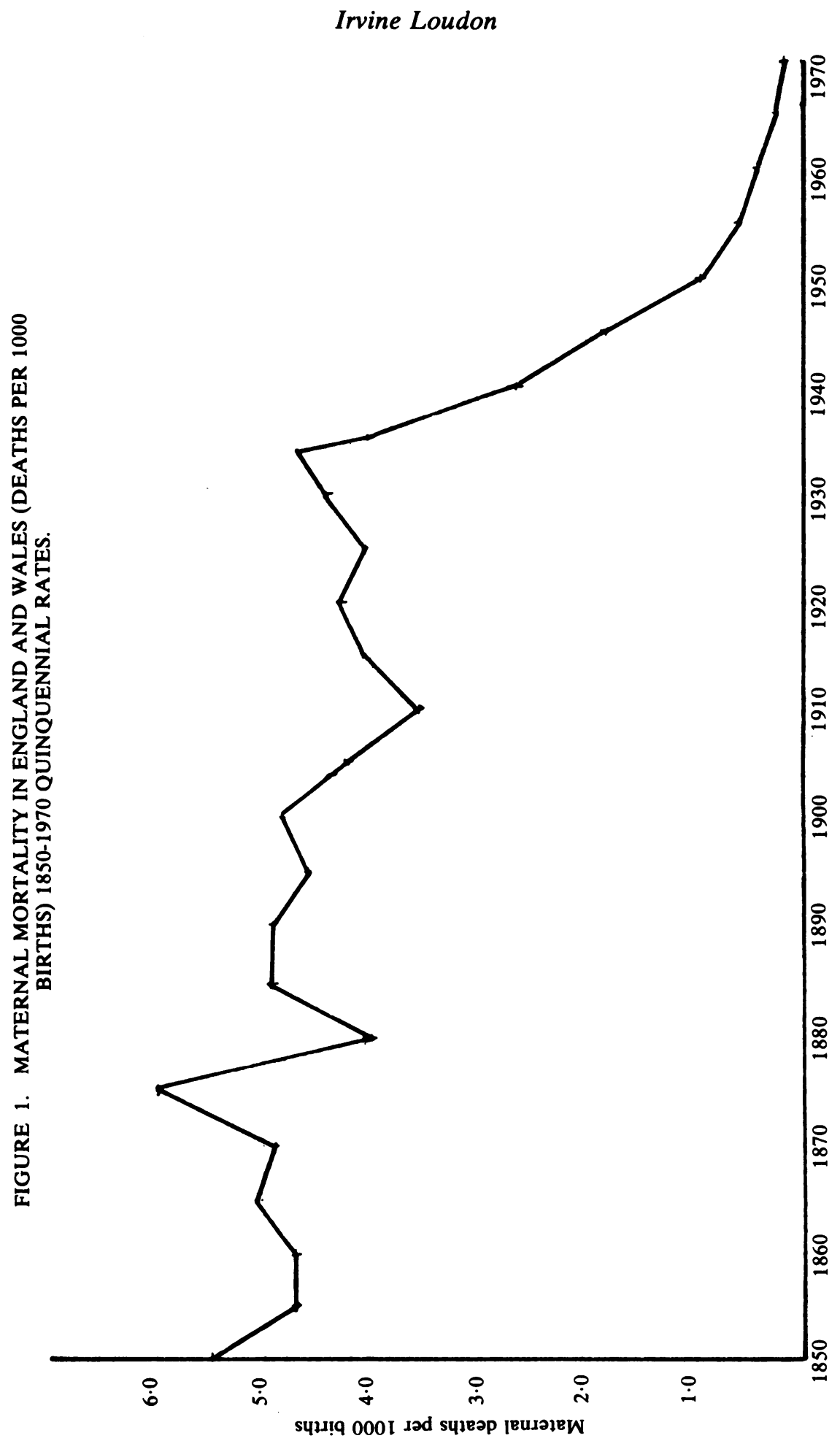




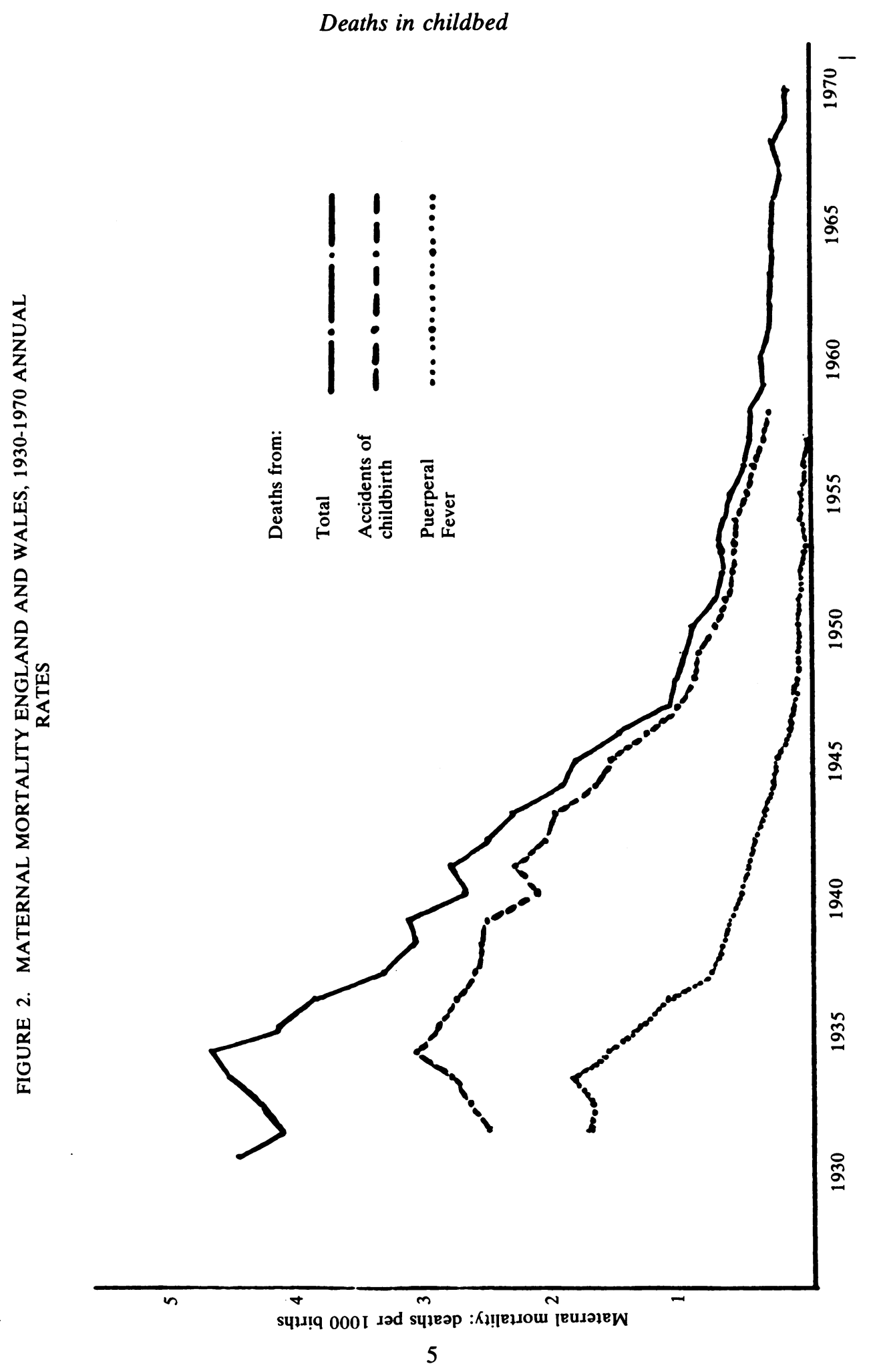




\section{Irvine Loudon}

for more than a century before the mid-1930s. It is not hard to understand why, for so long, the statistics of maternal mortality remained a continual reproach to the practitioners of obstetrics.

It was not until 1936 that maternal mortality rates began to fall. ${ }^{7}$ When they did, the fall was sudden, profound, and sustained. There is no more remarkable change in any health statistic during the twentieth century (figs. 1 and 2). There can be little doubt that this change was initiated by the introduction of the sulphonamides, ${ }^{8}$ but after the first few years it cannot have been the only factor. The reasons for the fall are discussed very briefly as a postscript to this paper, but a detailed discussion lies outside the scope of the study, which falls into three main sections.

In the first section the distribution of obstetric care between medical men and midwives is examined, and in the second, the position of obstetrics within the medical profession. Both are essential preliminaries to the third and main section in which an examination of the statistics is used as a means of investigating the standards of maternal health and obstetric care between the beginning of the nineteenth century and 1935.

\section{WHO UNDERTOOK THE DELIVERIES?}

Before 1730, midwives enjoyed a virtual monopoly of normal midwifery in London and probably an absolute monopoly in the provinces. The traditional view is that man-midwifery was rare or nonexistent before the early eighteenth century. ${ }^{9}$ Wilson, however, has shown convincingly that the term "man-midwife" was used in England in the early seventeenth century and that man-midwifery was probably a more or less routine part of surgical practice throughout that century. Nevertheless, the role of the surgeon was almost certainly that of intervention in abnormal labours when instruments were required. ${ }^{10}$ The remarkable innovation of the $1730 \mathrm{~s}$ was the attendance of medical practitioners at normal labours which they had agreed to attend beforehand. Until that period, it is reasonable to assume that most surgeons had little or no experience of normal labours, and, indeed, the mechanism of labour was not understood. ${ }^{11}$

\footnotetext{
${ }^{7}$ W. Taylor and M. Dauncey, 'Changing pattern of mortality in England and Wales. II. Maternal mortality',Br. J. prevent. soc. Med., 1954,8,172-175, concluded that 1937 was "the first year of sustained decline" in maternal mortality. They analysed the falls separately for deaths from puerperal sepsis, haemorrhage, and toxaemia and concluded that the introduction of prontosil was "one of the rare situations which endorse the identification of an agency of major importance as contributory to a statistical trend".

${ }^{8}$ The first sulphonamide to be used in clinical practice (by E. Anselm in 1935) was prontosil. The classic paper on the treatment of puerperal fever with this drug was Leonard Colebrook and Méave Kenny, 'Treatment with prontosil of puerperal infections due to haemolytic streptococci', Lancet, 1936, ii: 1319-1322. In this, they showed that treated patients suffered a mortality rate of four per cent compared to twenty per cent for untreated patients. Fortunately, over ninety-five per cent of puerperal infections were sulphonamide-sensitive. Colebrook and Kenny presented their results with commendable caution. See F. Hawking and J. Stewart Lawrence, The sulphonamides, London, H.K. Lewis, 1950.

${ }^{9}$ See especially J.H. Aveling, English midwives, London, 1872; J. Glaister, Dr William Smellie and his contemporaries, Glasgow, 1894; Jean Donnison, Midwives and medical men, London, Heinemann, 1977 , Herbert R. Spencer, The history of British midwifery from 1650-1800, London, John Bale, 1927, and for interesting sidelights on midwifery care there is much scattered information in Sarah Stone, $A$ complete practice of midwifery, London, 1737.

${ }^{10}$ Adrian Wilson, 'Childbirth in seventeenth- and eighteenth- century England', University of Sussex, DPhil thesis, 1984.
} 


\section{Deaths in childbed}

Why this remarkable change should have occurred when it did is debatable. As Wilson points out, "fashion and forceps" is the traditional explanation. In other words, that just as surgeons were becoming more fashionable, forceps were discovered in $1730^{12}$ and conferred great power and prestige on the man-midwife. At the same time, the establishment of lying-in hospitals, dominated by medical men, advertised the place of men in midwifery.$^{13}$ According to this view, forceps were the key to understanding the beginning of obstetrics as a branch of medicine. But the explanation is unsatisfactory. An alternative explanation may be the change that was taking place in the rank-and-file practitioners. About 1730, the surgeon-apothecary experienced a substantial rise in status and prosperity as he expanded his activities and looked for new openings in the thriving business of medical practice. ${ }^{14}$ Man-midwifery was an additional source of income and an excellent way to acquire and to keep a practice of regular patients. The expansion in the activity of the rank-and-file practitioners was accompanied by a demand for better medical education. Hospital training commenced around the middle of the eighteenth century and it was often combined with attendance at private courses in midwifery. Smellie arrived in London in 1739 and began teaching. ${ }^{15}$ One of his pupils was Richard Kay from Lancashire, who attended two courses of midwifery with Smellie in $1744 .{ }^{16} \mathrm{Kay}$ 's account of a course consisting of lectures followed by attendance at labours, first with Smellie and then on his own, must be one of the earliest accounts of a system of training which became routine by the nineteenth century.

Between 1750 and 1800, medical practitioners had established themselves as the proper attendants at all complicated labours and at as many normal ones as women would choose to employ them. While the opportunities for obstetric training increased rapidly for medical students, for midwives it remained with very few exceptions simply a process of "picking up" the art from the older woman. ${ }^{17}$ The

\footnotetext{
${ }^{11}$ When the midwife Sarah Stone practised in Bridgewater and Taunton between 1702 and c. 1730, there were no men-midwives, just as there was none during the time of her mother, Mrs Holmes. When, c.1730, she moved to Bristol, she found to her intense disgust that "every young MAN who hath serviced his apprenticeship to a Barber-Surgeon, immediately sets up for a Man-Midwife; although as ignorant, and indeed, much ignorantor than the meanest Woman of the Profession". Sarah Stone was witnessing the incursion of men into "her profession" and thus the start of the medicalization of childbirth. Stone, op. cit., note 9 above.

${ }^{12}$ The time when forceps were first used in England is uncertain. They were invented by the Chamberlens and kept secret for three generations, but there is evidence of their possession, if not their use, by a surgeon in Brentford in Middlesex in the late seventeenth or early eighteenth century. Their design was published in England for the first time in 1730 and thereafter they were widely known and used. (Wilson, op. cit., note 10 above.) However, evidence from Somerset shows they were not known or used by surgeons in Bridgewater as late as 1800 . (Jonathan Toogood, 'On the practice of midwifery, with remarks', Prov. med. sur. J., 1844, 103-108.) This suggests that the spread of the use of forceps in provincial England may have been slower than generally realized.

${ }^{13}$ The first lying-in hospital in England was the General Lying-In Hospital, established in 1739. The Lying-In Hospital, Dublin (The Rotunda), was established in 1745, and the first voluntary general hospital to open maternity wards was the Middlesex Hospital in London in 1747.

${ }^{14} \mathrm{I}$. Loudon, 'The nature of provincial medical practice in eighteenth-century England', Med. Hist., 1985, 29: 1-32.

${ }^{15}$ Glaister, op. cit., note 9 above.

${ }^{16} \mathrm{~W}$. Brockbank and F. Kenworthy (editors), The Diary of Richard Kay (1716-51) of Baldingstone, near Bury, Manchester, Chetham Society, 1968.

${ }^{17}$ In 1806, a medical practitioner in Suffolk wrote to say that three female practitioners had settled in the county "after hearing a course of lectures [on midwifery] in London". They were the first to have done so
} 


\section{Irvine Loudon}

licensing of midwives by bishops, (which never contributed substantial numbers) ceased during the eighteenth century, ${ }^{18}$ and the competence and education of women who adopted the role of midwife varied widely $;{ }^{19}$ but the only possible definition of midwives before the Midwives' Act of 1902 - a definition that says nothing about background or training - is that they were women who earned their living partly or entirely by the practice of midwifery and were recognized within their community for the possession of expertise in deliveries.

It is certain that the number of medical men practising midwifery increased rapidly between 1730 and 1800 , and that the midwives bitterly resented this invasion of what they believed was their territory. John Blunt was one of a number of laymen and medical men who joined forces with the midwives to attack man-midwifery. In 1793 he complained that "... there are 99 men-midwives for one midwife, and that the male practitioners are still increasing insomuch that five new ones (some men and some boys) have set up in one street near my house, within 200 yards of each other, during the last six months." 20 It is likely that this was a gross exaggeration; but his statement underlines the increase in the involvement of medical practitioners in midwifery.

From the middle of the eighteenth century, therefore, the following options were available to pregnant women: delivery at home by a medical practitioner or by a midwife; delivery as an in-patient in a lying-in hospital; or as an out-patient under the care of a dispensary or lying-in charity; or unattended delivery, meaning that labour took place in the absence of any "professional" (in the widest sense of that term) assistance. Unattended deliveries were still the rule in North Wales, ${ }^{21}$ and probably elsewhere in Britain, even at the end of the nineteenth century.

There are, in fact, no accurate data for the distribution of deliveries in each of the above categories, although Munro Kerr in 1933 suggested a simple answer to the question "Who undertook the deliveries from the eighteenth to the twentieth century?". Before 1750, he suggested, midwives predominated. From 1750 to 1900 , general practitioners delivered the majority of women, including most of the poor in the industrial areas. From the introduction of the Midwives' Act in 1902, midwives slowly began to regain the majority of deliveries in the urban areas, at least amongst the poor. ${ }^{22}$ This version, however, is too simple.

and were thus exceptional. (See note 23 below)

${ }^{18}$ Spencer, op. cit., note 9 above.

${ }^{19}$ Aveling, op. cit., note 9 above. D.N. Harley, 'Ignorant midwives - a persistent stereotype', Bull. Soc. soc. Hist. Med., 1981, 28: 6-9; Adrian Wilson, 'Ignorant midwives, a rejoinder', ibid., June 1983, 32: 46-49; and Bernice Boss and Jeffrey Boss, 'Ignorant midwives, a further rejoinder', ibid., December 1983, 33: 71 .

${ }^{20} \mathrm{John}$ Blunt, Man-midwifery dissected, London, S.W. Fores, 1793, pp. 48-49. (John Blunt was the pseudonym of the Piccadilly bookseller S.W. Fores.) See also: Leading article 'Sir Anthony Carlisle and man-midwifery', Lancet, 1826-27, 177-179, 456-461; 'Proprietas', Address to the public on the propriety of midwives instead of surgeons practising midwifery, London, 1826; Anon. Observations on the impropriety of men being employed in the business of midwifery, London, Hunt \& Clarke, 1827; M. Adams, Man-midwifery exposed, London, S.W. Fores, 1830; John Stevens, Man-midwifery exposed, London, 1849; W. Talley, He, or man-midwifery, London, 1863; Anon., The accoucheuse and the accoucheur, London, Cauldwell, 1864.

2138th Report of the Registrar General for 1875, 1877, p.234.

${ }^{22}$ Munro Kerr, op. cit., note 4 above, pp. xxiii-xiv. 


\section{Deaths in childbed}

In 1806 , for example, a number of reports of practice in the provinces were published, some of which included relative numbers of midwives and medical men. ${ }^{23}$ In Nottingham, for instance, there were at the beginning of the nineteenth century "15 surgeon-apothecaries all practising as men-midwives, and 11 midwives all uninstructed". In "the district of Nottinghamshire", however, there were "25 surgeon-apothecaries all undertaking midwifery and 123 midwives, all uninstructed". ${ }^{24}$ This report was in general confirmed by accounts from other provincial areas.

Matthew Flinders (1750-1802) of Donington in Lincolnshire, who practised as a surgeon-apothecary, was probably a typical country practitioner of the last quarter of the eighteenth century. He undertook normal midwifery on a routine basis and recorded in his diary his attendance at many normal labours, always noting the time he arrived at the patient's house and the time he left. In 1775, he attended forty-three deliveries, staying at the bedside from the onset of labour until its completion, often for twelve hours or more. In March 1775, he attended two cases in succession and noted that he "had not been in bed or my boots off for 40 hours". All except a few of the cases were described as "easy", "normal", or "excellent" labours, or at worst as "lingering" ones. None died. Although he regarded midwifery as tiring and tedious, and not well paid (half a guinea to one guinea a delivery), he saw it as central to his practice as a country surgeon and feared the competition of local midwives. ${ }^{25}$ Nevertheless, medical practitioners in England and Wales as a whole never obtained a monopoly of midwifery.

In 1843 , one writer asserted that "A larger proportion of the 500,000 English women who lie in every year and have any attendance at all [my italics] are attended by midwives." ${ }^{28}$ A report by a committee of the Obstetrical Society of London published in 1870 and 1871 included a description of the relative numbers of poor women attended in labour either by midwives or by medical men. ${ }^{27}$ There were large variations. In villages, the number attended routinely by midwives varied from thirty to ninety per cent. In small non-manufacturing towns - i.e., market towns - midwives attended at most ten per cent, nearly all being delivered by medical practitioners. In the large manufacturing towns, attendance by midwives was the rule, amounting to seventy-five to ninety per cent of all deliveries amongst the poor. In a large majority of deliveries amongst the poor in South Wales, especially in the industrial areas, midwives attended; in North Wales deliveries were said to be unattended, or attended only by "ignorant old women". ${ }^{28}$ In London, fifty per cent of deliveries in

\footnotetext{
${ }^{23}$ These reports were the published replies to a questionnaire sent out by Dr Edward Harrison of Horncastle, Lincs., in connexion with his plans for medical reform. They were published in Med. chirurg. Rev., 1806, 13.

${ }^{24}$ Ibid., pp. CI-CIII.

${ }^{25}$ Lincolnshire Archives Office, Lincoln. The diaries of Matthew Flinders, surgeon of Donington, Lincolnshire (1775-1802). His eldest son of the same name was the famous explorer and hydrographer whose name is to be found in Flinders Bay, Flinders River, and Flinders Island in Eastern Australia, as well as Flinders University.

${ }^{26}$ Leading article, 'Deaths in childbirth', Lond. med. Gaz., new series, 1: 1843-44, 747-749.

${ }^{27}$ 'Report of the Infantile Mortality Committee of the Obstetrical Society of London', Trans. Obstet. Soc. Lond., 1870, 12: 132-149; 1871, 13: 388-403.

${ }^{28}$ Williams (1904), op. cit., note 4 above, p.33.
} 
the East End were attended by midwives, but in the West End, two per cent or less, and in the suburbs - Wimbledon, for example - five per cent or less.

The Report of the Select Committee on Midwives' Registration in 1892, underlined the uncertainty about the number of midwives. ${ }^{29}$ The census of 1881 gave 2,646 as the number of women professing to act as midwives. But the committee was presented with estimates of between 10,000 and 20,000 as the true figure, and concluded that as many as 450,000 out of a total of about 800,000 deliveries took place solely under the care of midwives. ${ }^{30} \mathrm{Mr}$ Haywood, a general practitioner and medical officer of health from Lancashire, said that in his district "scarcely a fifth of the confinements are attended at any stage by a doctor; the work is done by women who practise as midwives". ${ }^{31}$ So large were local differences that it is extremely difficult to reconstruct a picture of midwifery for England and Wales as a whole in the nineteenth century. But a very large majority of the medical practitioners who undertook midwifery were general practitioners. The number who could be described in the modern sense as specialists or consultants, although they are prominent in the obstetric literature, were far fewer than consultant physicians and surgeons. Even by the end of the nineteenth century, as Dr Aveling commented in 1892, rarely, if ever, would one find - even in London - private practitioners who depended on midwifery alone. If anyone attempted to do so, he added, "I think it would kill him very soon". ${ }^{32}$ Instead, the consultant was a practitioner who, while undertaking a large amount of midwifery, combined it with practice as a physician, surgeon, or general practitioner.

THE MEDICAL CORPORATIONS, THE GENERAL PRACTITIONERS, AND ATTITUDES TO MIDWIFERY

Midwifery cut across the traditional boundaries of the tripartite division of the medical profession. By the end of the eighteenth century, it was practised by a few physicians, some hospital surgeons, and a large majority of surgeon-apothecaries. But midwifery lay outside physic, surgery, and pharmacy and was thus not accepted by any of the medical corporations. The College of Physicians asserted their responsibility for disorders of women before and after labour, but not during it. Intra-partum care was a manual operation, and the essential messiness and immodesty of delivering a baby made it, in the view of the President of the College, unsuitable for a gentleman with a university education. ${ }^{33}$ In 1783 , the College introduced a licence in the ars obstetrica, which it conferred on a few physician

\footnotetext{
${ }^{29}$ Select Committee on Midwives' Registration, PP 1892, XIV, p.144.

${ }^{30} \mathrm{The}$ estimate - fifty-six per cent of deliveries by midwives - is close to the estimate of Munro Kerr in 1933 of sixty per cent for England: in Scotland the corresponding figure was thirty per cent.

${ }^{31}$ Loc. cit., note 29 above, Q.931. Fifteen years later, it was estimated that fifty per cent of women in England and Wales were delivered by midwives. Examples of regional variation were the following percentages of midwife deliveries: Newcastle upon Tyne 11.2\%; London 25\%; West Riding, Yorks, 35\%; Hertford 39.5\%; Lancaster 49.9\%; Liverpool 52\%; Manchester 60.9\%; Derby 62.5\%; Salford 76.5\%; Gloucester 83.6\%; St Helens 93\%; Lancashire, urban districts 50.8\% - rural districts 30.9\%. Report of the Departmental Committee appointed by the Lord President of the Council to consider the working of the Midwives Act 1902, PP 1909, XXXIII, para. 23.

${ }^{32}$ Loc. cit., note 29 above $Q .341$.

${ }^{33}$ Select Committee on Medical Education, PP 1834, XIII, Q.232.
} 


\section{Deaths in childbed}

man-midwives before it was discontinued in 1800 . This licence, however, was no more than a kind of honorary conferment and implied no responsibility on the part of the College for the teaching of midwifery or the examination of candidates. ${ }^{34}$ The Royal College of Surgeons in London, established in 1800, was a new institution intent on creating a small tight élite of London hospital surgeons. They held the practice of both midwifery and pharmacy (the hallmarks of the general practitioner) in contempt. To practise either was to be excluded from office or position within the College. The senior members of the Society of Apothecaries, essentially a City company concerned with the wholesale drug market, had little clinical experience of any kind, least of all in midwifery. In spite of administering the licence held by most general practitioners, the Society was the least suited of the three corporations to take midwifery under its wing.

Responsibility for midwifery fell, therefore, to the general practitioners when they emerged under that name in the second and third decades of the nineteenth century, proclaiming themselves as "general practitioners in physic, surgery, pharmacy and midwifery". From 1815, it was customary for most general practitioners to hold the Licence of the Society of Apothecaries and the diploma of Membership of the College of Surgeons. At first, neither qualification included an examination in midwifery, so that it was alone in that "there are no means of ascertaining the qualifications of persons who take it in charge" ${ }^{35}$ The history of the education of the general practitioner from 1815 was notable for an ever-increasing emphasis on the biological sciences, physic, surgery, and pathology. Obstetrics had to struggle desperately for a proper place in the curriculum.

In 1827, twelve years after it was introduced, the Licence of the Society of Apothecaries included for the first time the requirement that students should have attended two courses of lectures on midwifery, and the revised regulations in 1835 added "practical instruction" to this requirement. But there was never a separate examination. Instead, from 1827, the examination in the Principles and Practice of Medicine included questions on the pregnant and puerperal woman and diseases of children. The Royal College of Surgeons in London introduced a Diploma in Midwifery in 1852. In 1876, three women - Sophia Jex-Blake, Miss Thorne and Miss Pechey - applied to take the examination, and the examiners resigned rather than examine them. London introduced a separate examination in midwifery for the final MB in 1841, and the conjoint examination of the Colleges of Physicians and Surgeons did the same, but not until $1884 .^{36}$

A.B. Granville established the Obstetrical Society of London in 1825 "to raise to a proper and dignified status, the practitioners in midwifery". ${ }^{37}$ (The society faded out

\footnotetext{
${ }^{34}$ Sir George Clark, $A$ history of the Royal College of Physicians of London, vol.2, Oxford, Clarendon Press, 1966. See also for a justifiably caustic comment on the Royal College of Physicians. E. Harrison, Remarks on the ineffective state of the practice of physic, London, 1806, p.13. In 1804, the College introduced a regulation whereby anyone practising as a physician-accoucheur was barred from election as a Fellow.

${ }^{35}$ A.B. Granville, correspondence, Lancet, 1830-31, i: 301-302.

${ }^{36} \mathrm{For}$ a detailed account of the regulations of the Licence of the Society of Apothecaries see 'Society of Apothecaries: intelligence', Med. quart. Rev., 1835, 4; 511-518. For the College of Surgeons' Diploma in Midwifery and the Sophia Jex Blake affair, see Sir Zachary Cope, The Royal College of Surgeons of England, a history, London, Anthony Blond, 1959, chs. 14 and 15, pp.121-132.
} 


\section{Irvine Loudon}

and was re-established in 1858.) This, together with the details of examinations given above, simply underlines the low regard for obstetrics which sprang from the rejection of midwifery by the medical corporations. Donnison has described how obstetricians were snubbed in society by people who would consider physicians and surgeons as socially acceptable. ${ }^{38}$

Thus obstetrics was regarded, even at the end of the nineteenth century, as an "extra" not worthy of the time devoted by students to the study of physic, surgery, or the pre-clinical sciences. Dr Elizabeth Garrett Anderson in 1898 saw a direct connexion between the low status of midwifery and the high rate of maternal mortality:

It is unfortunately true that the puerperal mortality all over England is higher than it ought to be.... The responsibility for this rests in great measure with the examining bodies. When they recognise that a sound and extensive knowledge of practical midwifery is infinitely more important to a practitioner than a minute acquaintance with organic chemistry and with the refinements of physiology there will be a chance of improvement, but not till then .... If every medical student were compelled to spend six months in acquiring skill in midwifery, the puerperal mortality all over the country would soon approach that which $I$ think it is at the present moment in the London maternity charities, namely, about 1 in $500 .^{39}$

In spite of its poor rating in medical schools, general practitioners embraced the practice of midwifery. It rapidly became the accepted wisdom that the key to success as a family doctor lay in the successful practice of midwifery. "The successful practice of midwifery... at the outset of life as surely establishes a professional man's reputation as the contrary retards his progress", wrote a Bridgewater practitioner in $1844 .^{40}$ Likewise, a maternal death was the most tragic and disturbing event in general practice. Even when such deaths were common, they could ruin a reputation. "The unfortunate termination of a surgical or medical case", wrote a general practitioner in 1809 , "will in time be forgotten; but the unlucky death of a midwifery patient (and chance has too great an influence in these cases) begets the greatest distrust, and often ruins his reputation and future prospects for ever" ${ }^{41}$

John Greene Crosse of Norwich, well known as a hospital surgeon, spent much of his time attending midwifery cases, both as the normal attendant and through being called in by other practitioners as a consultant. One of the first he attended, just after arriving in Norwich in 1815, happened to die of sepsis through no fault of Crosse's.

\footnotetext{
${ }^{37}$ Augustus Bozzi Granville (1783-1872), the son of the postmaster general in Milan, came to London in 1817 to practise medicine. Sir Walter Farquhar advised him to go to Paris for a year to learn midwifery, and on his return, Granville was appointed physician-accoucheur to the Westminster General Dispensary. He wrote extensively on obstetrics and was the founder of the Obstetrical Society of London. On the latter see Report of the Select Committee on Medical Education, PP 1834, XIII, evidence of Sir Charles Clark, Q.4179-4220.

${ }^{38}$ Donnison, op. cit., note 9 above, pp.42-43

${ }^{39}$ Elizabeth Garrett Anderson, 'Deaths in childbirth', Br. med. J., 1898, ii: 839-840, 927.

${ }^{{ }^{\circ}}$ Toogood, op. cit., note 12 above. Until recently, it was common for vacant partnerships or assistantships in general practice to include the words "midwifery essential".

'1'H' (Letter) Med. phys. J., 1809, 21: 382-385. Amongst the labouring classes of the nineteenth century there seems to have been a fatalistic acceptance of infant mortality, possibly because of the large families. Thus the statement of a mother, for instance, that she had borne nine children and "lost" five in childhood, was a commonplace. The same fatalism did not apply to maternal deaths. Midwives and medical men tended to be held directly responsible for the tragedy of a dead mother.
} 


\title{
Deaths in childbed
}

Unfortunately, through his attendance on this case he was unable to attend a poor woman whom he had promised to deliver free of charge. The latter was therefore delivered by an "ignorant old woman" and came to no harm. This episode so damaged his reputation that it was over three years before he could begin to build what was to become a very large practice in midwifery. ${ }^{42}$ The readiness with which the practitioner was blamed was confirmed at the end of the century by Dr Rentoul:

\begin{abstract}
When a hearse follows us into a street after a confinement it is most likely to ruin our practice in that particular street; for the nurses and others begin saying that puerperal fever has followed us. We are accused first, the nurse next, and after that the house, the sanitary arrangements .... It comes to this that practically every doctor who loses a confinement case receives very great blame, no matter whether he deserves it or not, very serious blame indeed. ${ }^{43}$
\end{abstract}

Midwifery was essential to retain the patients in general practice, but it was risky, anxious, time-consuming, and, in view of the hours spent, not profitable financially. ${ }^{44}$ Moreover, it was undertaken against a background of poor obstetric education. Most who started in general practice had only the dimmest idea of the conduct of normal, let alone complicated, labours, and learnt by hard and often bitter experience. The opinion of Mr Brown, MRCS, LSA, was echoed over and over again by his fellow practitioners: "I have no hesitation in saying, after more than thirty years' experience as student and practitioner that midwifery is the most anxious and trying of all medical work and to be successfully practised calls for more skill, care and presence of mind on the part of the medical man than any other branch of medicine."45

The concept of the general practitioner as the family doctor, which grew steadily through the second half of the nineteenth century, was centred around the delivery of the baby ${ }^{46}$ The young family doctor would deliver the baby, and, if it was a girl, attend her through infancy and childhood and inquire tenderly after her progress until she, too, engaged him to deliver the next generation of the family. A general practitioner might loathe the long night vigils and the anxiety of midwifery, but he had to conform. Small wonder, therefore, that general practitioners were so possessive about midwifery. Their opposition to the Midwives' Act is not one of the happier episodes in the history of general practice, but it is easy to understand the roots of their opposition. ${ }^{47}$

\section{MATERNAL MORTALITY BEFORE 1850}

There are no reliable estimates of maternal mortality before, at the earliest, the late eighteenth century. Eccles suggested an average rate of twenty-one per 1,000

\footnotetext{
${ }^{42}$ Library of the Wellcome Institute for the History of Medicine. The midwifery notebooks of John Greene Crosse of Norwich. MS. 1916, 1917. Another important account of midwifery in the pre-registration period is the notebook of Richard Paxton of Maldon in Essex for the period 1760-99, in the same library, MS 3820 .

${ }^{43}$ Loc. cit., note 29 above, Q.361 and 466.

"In the $1890 \mathrm{~s}$, however, when midwives' fees were from $2 s$. $6 \mathrm{~d}$. to $10 \mathrm{~s}$. per case, doctors amongst the poor would sometimes charge as little as $5 \mathrm{~s}$. to $7 \mathrm{~s}$. $6 \mathrm{~d}$. for a midwifery case, payable by instalments. Ibid., p.415. These fees were substantially lower than those charged by medical practitioners in the late-eighteenth century when half a guinea was the lowest and one guinea was common.

${ }^{45}$ Ibid., Q.1660.

${ }^{46} I$. Loudon, 'The concept of the family doctor', Bull. His. Med., 1984, 58: 347-362.

${ }^{47}$ Donnison. op. cit., note 9 above. ch. 6, is a notable account of the opposition to the Midwives' Act.
} 


\section{Irvine Loudon}

births for London between 1657 and 1700 , with wide annual variations. ${ }^{48}$ Willmott Dobbie estimated a rate of between 24.4 and 29.4 per thousand baptisms in three Somerset parishes between the sixteenth and eighteenth centuries. ${ }^{49}$ M.C. Buer quoted values of 16.7 per 1,000 in 1760 and 15 per 1,000 in 1781 as the maternal mortality based on the London Bills. ${ }^{50}$ Charles White of Manchester believed that maternal mortality in London was 13.9 per 1,000 from 1737-1772, 12.5 per 1,000 in Northampton between 1754 and 1772, while in Manchester it fell from 9.6 per 1,000 from $1754-59$ to 8.3 per 1,000 for 1,000 for $1759-65$ and to only 5.1 per 1,000 in 1771.51

TABLE 2. DOMICILIARY MIDWIFERY IN THE NINETEENTH CENTURY.

Reports from private practice showing the author, his status, the period in which the deliveries took place, the number of deliveries, the forceps rate and the maternal mortality.

\section{Author and date of publication}

1. S. Merriman 1814

2. E. Copeman 1841-42

3. J Waddington 1843-44

4. J. Toogood 1844

5. C. Earle 1846

6. Anderson Smith 1859

7. Robert Dunn 1859-60

8. Wm. Farr 1870 quoting

9. Fleetwood Churchill 1872

10. H.W. Bailey 1860

$$
\begin{gathered}
\text { Professional } \\
\text { status }
\end{gathered}
$$
Period in which the deliveries took place

Number of
deliveries

Forceps
rate

Maternal mortality per 1000 deliveries

$$
\text { P }
$$

Ma

$$
\text { p }
$$

General
practitioner
Margate

Physician accoucheur

Bridgewater

Surgeon

Norfolk

General

practitioner

General

practitioner

Mr Rigden

General

practitioner

Canterbury

Consultant

obstetrician

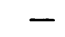

1835-41

1800

$0 \cdot 6 \%$

$5 \cdot 0$

840

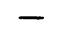

2159

$0 \cdot 1 \%$

0.9

1788-1844

c. $1810-17$

1135

$1 \cdot 3 \%$

$7 \cdot 0$

1800-46

4320

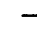

$3 \cdot 9$

1300

$2 \%$

$0 \cdot 8$

1831-50

4049

$0 \cdot 5 \%$

$6 \cdot 7$

$1860 \mathrm{~s}$

4390

$2 \cdot 05$

1831-70

2547

$1 \cdot 6 \%$

$6 \cdot 6$

General

practitioner

Thetford

1808-58

6476

$1 \cdot 7 \%$

\footnotetext{
${ }^{48}$ Audrey Eccles, 'Obstetrics in the seventeenth and eighteenth centuries and its implication for maternal and infant mortality', Bull. Soc. soc. Hist. Med., 1977, 20: 8-11.

${ }^{40}$ B.M. Willmott Dobbie, 'An attempt to estimate the true rate of maternal mortality, sixteenth to eighteenth centuries', Med. Hist., 1982, 26: 79-90.

${ }_{59}$ M.C. Buer, Health, wealth and population in the early days of the Industrial Revolution, London, Routledge, 1926, p.147.

${ }^{51}$ Charles White, $A$ treatise on the management of pregnant and lying-in women, London, 1772.
} 


\section{Deaths in childbed}

\section{Author and \\ date of \\ publication}

11. S. Lawrence 1862-63

12. Dr. Thomson 1867-68

13. Grailly

Hewitt

1868

14. W.T. Greene 1878

15. E. Copeman* 1874

16. H.C. Rose** 1876

\author{
Professional \\ status
}

Number of
deliveries

1000

2200

General

practitioner

Wanbury,

Chesire

Consultant

obstetrician

General

practitioner

Consultant

obstetrician

Norfolk

General

practitioner

Hampstead
Period in which
the deliveries
took place

$1850-68$

$1846-66$

$1869-77$

c. $1850-74$

-

$\begin{array}{cc}\text { Forceps } & \text { Maternal } \\ \text { rate } & \begin{array}{l}\text { mortality } \\ \text { per } 1000 \\ \text { deliveries }\end{array}\end{array}$

$5 \cdot 0$

0.9

$10 \cdot 2$

$8 \cdot 0$

$83 \cdot 0$

$1 \cdot 6$

* All cases "attended in consultation ... therefore of an unusually severe or complicated character". None "attended alone as ordinary cases of midwifery". Compare the results achieved by the same author as a young general practitioner: 2 , above.

** "The majority of cases amongst the well-to-do people ... none amongst the paupers."

N.B. The results recorded by consultant obstetricians include complicated cases to which the consultant was called either by a midwife, or, more usually, by a general practitioner. They therefore could be expected to show a higher mortality rate than the cases of general practitioners.

\section{Sources:}

1. S. Merriman, A synoposis of the various kinds of difficult kinds of parturition, London, Callow, 1814.

2. E. Copeman, 'Report on midwifery in private practice', Prov. med. Surg. J. 1834, 3.

3. Joshua Waddington, 'Statistics of midwifery', Lond. Med. Gaz., 1843-44, 2: 144-145.

4. Jonathan Toogood, 'On the practice of midwifery with remarks', Prov. med. surg. J., 1844, 103-108.

5. C. Earle, 'Report on obstetric cases occuring in private practice', ibid., 1846, 261-263

6. Anderson Smith, ' 1300 midwifery cases attended in private practice', Lancet, 1859 , i: 481.

7. Robert Dunn, 'On the statistics of midwifery from the records of private practice', Trans. Obstet. Soc. Lond. 1859-60, 1: 279-297.

8. W. Farr, Report of the Registrar General for 1870, p.410.

9. Fleetwood Churchill, 'Report of private obstetric practice for twenty-nine years', Dublin J. med. Sci., 1872, 53: 525-540.

10. H.W. Bailey, 'Statistics of midwifery'. Trans. Obstet. Soc. Lond., 1860, 2: 299-307.

11. S. Lawrence, 'Statistical report of 1000 midwifery cases', Edinb. med. J. 1862-63, 8: 712-724, 800-814.

12. Dr Thomson, 'A few notes on country obstetric practice', Edinb. med. J., 1867-68, 13: 69-71.

13. Grailly Hewitt, 'On puerperal fever', Trans. Obstet. Soc. Lond., 1868, 10: 69-92.

14. W.T. Greene, 'A synoposis of one thousand consecutive labours', ibid., 1878, 19: 204-217.

15. E. Copeman, 'Statistical and practical remarks on consultation midwifery in private practice', ibid., 1874, 16: 103-110.

16. Henry Cooper Rose, 'A contribution to the statistics of midwifery in private practice', ibid., 1876, 18: $146-159$. 


\section{Irvine Loudon}

TABLE 3. MATERNAL MORTALITY.

Mortality rates, expressed as deaths per 1000 births, recorded at domicilliary deliveries: dispensaries, lying-in (out-patient) charities, and the out-patient divisions of certain lying-in hospitals

Source

Institution

Period of
deliveries

No. of
deliveries

Forceps
rate
$\%$

$1774-80$

1819

1848-59

1848-59 (1860)

4. T. H. Bickerton (1936)

5. F.M. Ramsbotham $E$. District of the (1829)

6. F.M. Ramsbotham (1843-44)

7. J. Hall Davis
Benevolent

Institution

\section{Westminster \\ Dispensary}

Liverpool Ladies

Charity

Royal Maternity

Charity*

Royal Maternity Charity*

8. Select Committee Royal Maternity on Midwives Charity*

\section{(1892)}

9. Select Committee Out-patient

on Midwives

Registration (1892)

divisions of:

City of London Lying-in Hospital

Queen Charlotte's

Hospital

British Lying-in

Hospital

General Lying-in

Hospital

10. Sir George Newman

Queen's Institute

Midwives

\section{Maternal \\ (deaths per \\ 1000 \\ deliveries)}

$3 \cdot 7$

$5 \cdot 8$

$2 \cdot 2$

$1 \cdot 6$

$1 \cdot 3$

$1 \cdot 3$

1889

$0 \cdot 8$

1889

1924-33

over

*The Royal Maternity Charity covered an area of three miles' radius around St Paul's Cathedral, and was divided into South, East, and West divisions, each under the charge of a physician-accoucheur. In the $1880 \mathrm{~s}$, the percentage of deliveries to which a medical practitioner was called lay between three and four per cent. Otherwise, the patients were under the sole care of trained midwives.

\section{Sources:}

1. Bland, op. cit., footnote 52 .

2. Granville, op. cit., footnote 53 .

3. A.B. Granville, 'Phenomena, facts and calculations connected with the power and act of propagation in females of the industrial classes in the metropolis institutions', Trans. Obstet. Soc. Lond., 1860, 2: 139-196.

4. T.H. Bickerton, A medical history of Liverpool, London, John Murray, 1920, p. 216.

5. and 6. F.M. Ramsbotham, 'Table of difficult midwifery cases', Lond. Med. Gaz., 1829, 3: 284-286; and 'Report on the Royal Maternity Charity', ibid., 1843-44, new series 2: 142-143 and 619-623. 


\section{Deaths in childbed}

7. J. Hall Davies, Parturition and its difficulties, London, Hardwicke, 1865.

8. and 9. Select Committee on Midwives Registration, 1892, XIV.

10. Sir George Newman, The building of a nation's health, London, Macmillan, 1939.

\section{The Dispensaries and Private Practice}

How do these values compare to those of midwifery practice in the late eighteenth century and the first half of the nineteenth century? The answers are summarized in tables 2 and 3, which include the statistics of private and dispensary practice respectively. The reports in these tables were chosen with care on the basis of evidence of careful written records kept, in many cases, over a period of several decades. A number of reports where the author depended on his memory, or the number of cases was too small, were rejected. Individually, the reports may be of limited statistical value. Collectively, however, they provide evidence of a remarkably low maternal mortality, especially when compared to the mortality experienced in the twentieth century. Robert Bland's report of the midwifery department of the Westminster General Dispensary, published in 1781, is, as far as I know, the first comprehensive account of an unselected series of deliveries amongst the poor. Carefully compiled and thoughtfully discussed, the report is based on 1,897 deliveries between 1774 and $1780 .^{52}$ The maternal mortality rate was 3.7 per 1,000 deliveries amongst a population living in poverty under some of the worst conditions of urban squalor. At this, as at other dispensaries and the out-patient lying-in charities in the eighteenth and nineteenth centuries, midwives were engaged and paid by the institution. They were subject to strict rules and were instructed by the physician- or surgeon-accoucheurs of the charity who attended all complicated cases. Granville published as an appendix to his book an impressively sensible and comprehensive set of instructions for the midwives of the Westminster General Dispensary. ${ }^{53}$ Almost certainly, the dispensary midwives, by selection, training, and regulation, provided a higher standard of obstetric care than the private "midwives" of the poor areas who, on many occasions, may have combined midwifery with the treatment of ordinary septic conditions or the laying-out of the dead. ${ }^{54}$

In 1882, Granville published a similar report to Bland's. ${ }^{55}$ There were 687 deliveries with a maternal mortality of 5.8 per 1,000 amongst patients living "in the utmost state of wretchedness and want... being confined in small, cold and damp

\footnotetext{
${ }^{52}$ Robert Bland, 'Midwifery reports of the Westminster General Dispensary', 1781. Full title: 'Some calculations of the number of accidents or deaths which happen in consequence of parturition; and of the proportion of male to female children, as well as of twins, monstrous productions, and children that are dead-born; taken from the midwifery reports of the Westminster General Dispensary: with an attempt to ascertain the chance of life at different periods, from infancy to twenty-six years of age; and likewise the proportion of natives to the rest of the inhabitants of London. In a letter from Robert Bland, MD, Physician-Man-Midwife to the Westminster General Dispensary, to Samuel Foart Simmons, MD FRS', Phil. Trans. R. Soc. Lond. 1781, 71: 155-171.

${ }^{53}$ A.B. Granville, $A$ report on the practice of midwifery at the Westminster General Dispensary during 1818 , London, 1819, pp.201-220.

${ }^{54}$ Jane Lewis, The politics of motherhood: child and maternal welfare in England, 1900-1939, London, Croom Helm, 1980, pp.149-151. Since the handywomen, even in the 1920s, combined the occupations of midwife with laying out the dead, it is a reasonable assumption that this tradition went back at least to the mid-nineteenth century.

${ }^{55}$ A.B. Granville, 'A report of the practice of midwifery at the Westminster General Dispensary during 1819', Lond. med. phys. J., 1822, 47: 282-288, 374-378.
} 


\section{Irvine Loudon}

rooms, either in cellars or garrets". Both Bland and Granville presented their results so that we know how many cases were delivered, as Granville put it, "without the slightest interference, by nature alone", and how many, as Bland put it, with "little more than common assistance". From such data we can estimate how many patients might have been expected to survive an unattended labour. The answer from both reports is between 97 and 97.5 per cent; in other words, a mortality rate of twenty-five to thirty per thousand deliveries, and this may well verge on the side of pessimism. Although this is no more than a rough estimate, it does suggest that institutions or obstetricians whose records showed a mortality rate of thirty per 1,000 or more were almost certainly increasing the risks of childbirth, while those achieving a rate of fifteen, or less than ten, were probably providing worthwhile obstetric care. But many of the lying-in charities and dispensaries did a great deal better. The Royal Maternity Charity, for example, which covered a three-mile radius from St. Paul's Cathedral, produced consistently low maternal mortality rates. Even the figure of 4.6 in 1843-44 (table 3, no. 6) is inflated because it contained associated deaths; the puerperal mortality was 3.5. Otherwise, the results speak for themselves.

The data from private practice (table 2), some of which encroach on the second half of the nineteenth century, are more suspect in one respect; they are probably not representative. It is a reasonable assumption that practitioners in the emotive subject of family obstetric practice who obtained poor results (whether they were to blame or not) would not have advertised the fact. Nevertheless, they show that low mortality rates could be achieved by some general practitioners and some consulting practitioners, although the latter would have had the added problem of an excess of complicated cases.

How was it possible for maternal mortality rates as low or lower than the national rates of the 1920 s and early 1930 s to be achieved before the introduction of anaesthesia, antisepsis, or twentieth-century methods? The answer is probably that the management of normal labour, and of the common complications, although remarkably poor at the beginning of the eighteenth century, ${ }^{56}$ was remarkably good, or at least well understood, at the end. Denman's account of the management of normal labour could, with minor amendments, almost stand as a text for today. ${ }^{57}$ Deaths in childbed could be substantially reduced much more by simple routine good practice than by highly skilled manoeuvres. Correction of bad practice and unnecessary interference such as manual dilatation of the cervix was as important as the instillation of good practice. The introduction of forceps was a real advance for two reasons. First, because they largely replaced the brutal and dangerous perforator, hook, and crotchet; ${ }^{58}$ second, because obstetricians between 1770 and

\footnotetext{
${ }^{58}$ William Clark, The province of midwives, Bath, 1751. In this treatise, written for the instruction of midwives, manual dilatation of the cervix in labour and getting the woman to bear down on an undilated cervix was recommended as a routine procedure.

${ }^{57}$ T. Denman, An essay on natural labours, London, 1786; and An introduction to the practice of midwifery, 5th ed., London, 1805.

${ }^{58}$ Edmund Chapman, $A$ treatise on the improvement of midwifery, London, 1759. Chapman blamed the use of the perforator and hook for "The malicious but false Report, that wherever a MAN comes, the MOTHER, or CHILD, or BOTH must necessarily die."
} 


\title{
Deaths in childbed
}

about 1860 tended to be very - even excessively - conservative in their use..$^{59}$ This can be seen in tables 2 and 3, and David D. Davies (the first professor of midwifery in London) believed that forceps were necessary, at the most, only once in every 250 to 300 cases. ${ }^{60}$ Today, the forceps rate in a general practitioner maternity unit is usually about five to seven per cent, and the rate in National Health Service hospitals is about fifteen per cent. ${ }^{\text {B1 }}$

In short, the low maternal mortality achieved by some dispensaries and some practitioners suggests that obstetrics had reached quite a high level in the space of fifty or sixty years following the mid-eighteenth century. That was more than could be said of physic, surgery, or pharmacy during that period. But it was not true of obstetrics in the institutions where surgery was beginning to advance - the hospitals.

\section{The Lying-in Hospitals}

It was William Farr who remarked in 1870 that:

\begin{abstract}
Seeing how destitute of comforts, means, and medical appliances many women are, the thought occurred to some benevolent person that they might be received and delivered in hospitals. It was the extension of the hospital system to midwifery cases, which have some analogy with wounds and injuries for which hospitals had been used from the date of their foundation. Contrary to expectations the advantages these institutions offered were over-balanced by one dread drawback; the mortality of mothers was not diminished; nay it became in some instances excessive; in other instances appalling. ${ }^{\text {22 }}$
\end{abstract}

The contrast between the mortality rate of domiciliary practice and the rates of the British Lying-In Hospital are shown here in table $4 .^{63}$ Charles White quoted the mortality rates at three unnamed London lying-in hospitals as ranging from 19.5 per 1,000 deliveries to 39 per 1,000 during the eighteenth century. At a fourth hospital it was only 7.5 per $1,000,,^{64}$ and when he sought the reason, he was told it was because they avoided the overcrowding that occurred at the other institutions, foreshadowing the remark of Dame Janet Campbell in 1935 that "one of the dangers of maternity hospitals is overcrowding". ${ }^{65}$ However, a high hospital mortality rate was not confined to the eighteenth century. The rate at Queen Charlotte's Hospital between 1857 and 1879 was on average 29.6 per 1,000, reaching the spectacular levels of 84.4

${ }^{59}$ See A.W. Edis, 'The forceps in modern midwifery', Trans. Obstet. Soc. Lond., 1878, 19: 69-92.

${ }^{\circ} \mathrm{J}$. Waddington, 'Statistics of midwifery in private practice', Lond. med. Gaz., 1843-44, new series 2: 144-145. See also Robert Lee, 'Clinical reports of difficult cases in midwifery', ibid., 1838-39, n.s. 2: 827-832.

${ }^{61}$ A. Macfarlane and M. Mugford, Birth counts: statistics of pregnancy and childbirth, London, HMSO, 1984 , table A.7.32. Forceps rates as percentage of all deliveries rose from $3 \cdot 7 \%$ in 1953 to $5 \cdot 1 \%$ in 1963 and $13.3 \%$ in 1978 .

6233rd Report of the Registrar General for 1870, 1872, p.407.

${ }^{63}$ An account of the British Lying-In Hospital for Married Women in Brownlow Street, London, 1797. For a very extensive account of data on mortality in lying-in hospitals in various countries see A. Hirsch, Handbook of geographical and historical pathology, translated by C. Creighton, London,New Sydenham Society, 1885, pp.416-474, and esp. table, pp.422-431. Hirsch believed that puerperal fever was primarily a disease of lying-in hospitals, but he also produced a list of reports from the eighteenth and nineteenth centuries showing that it could be spread by medical practitioners and underlining the special risk of transmission from cases of erysipelas. For additional information on historical aspects of maternal mortality in various countries in Europe and the USA see E. Shorter, A history of women's bodies, London, Allen Lane, 1982, especially the supplementary tables, pp.311-317.

${ }^{6}$ White, op. cit., note 51 above. The lying-in hospital can be identified as the Westminster Lying-In Hospital, later the General Lying-In Hospital, York Road.

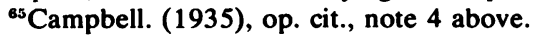


TABLE 4. THE MATERNAL MORTALITY RATE IN THE BRITISH LYING-IN HOSPITAL IN THE EIGHTEENTH CENTURY AND IN QUEEN CHARLOTTE'S HOSPITAL IN THE NINETEENTH CENTURY.

The British Lying-in Hospital

\begin{tabular}{lcc}
\multicolumn{1}{c}{ Period } & $\begin{array}{c}\text { Number of } \\
\text { deliveries }\end{array}$ & $\begin{array}{c}\text { Maternal } \\
\text { mortality rate }\end{array}$ \\
$1749-58$ & $23 \cdot 8$ \\
$1759-68$ & $20 \cdot 0$ \\
$1769-78$ & $18 \cdot 8$ \\
$1779-88$ & $16 \cdot 6$ \\
$1749-96$ & $16 \cdot 0$ \\
Worst years: & 24,079 \\
1760 & \\
1770 & \\
& \\
Source: An account of the British Lying-in \\
hospital for married women in Brownlow Street, \\
London, 1797. \\
Library of the Wellcome Institute for the History \\
of Medicine, London.
\end{tabular}

Queen Charlotte's Hospital

Period $\quad \begin{gathered}\text { Number of } \\ \text { deliveries }\end{gathered} \quad \begin{gathered}\text { Maternal } \\ \text { mortality rate }\end{gathered}$

$1860-64$

$1746 \quad 42 \cdot 4$

$1865-69 \quad 1918 \quad 18 \cdot 2$

$1870-74 \quad 2228 \quad 22 \cdot 0$

$\begin{array}{lll}1875-79 & 2201 & 26 \cdot 8\end{array}$

1880-84 $\quad 3401 \quad 10 \cdot 5$

$1885-89 \quad 4564 \quad 4 \cdot 2$

$1890-94 \quad 4894 \quad 5.9$

$1895-99 \quad 5638 \quad 4 \cdot 2$

$\begin{array}{lll}1900-02 & 3738 & 4 \cdot 5\end{array}$

Source: Williams (1904), op. cit., footnote 4, table XVIII, p. 42.

TABLE 5. THE CAUSES OF MATERNAL MORTALITY: $1872-76$ and 1930

$\begin{array}{ll}\text { No. of } & \text { \% of } \\ \text { deaths total }\end{array}$

Puerperal fever

Accidents of childbirth

$\begin{array}{lrr}\text { Flooding } & 3,524 & 15 \cdot 3 \% \\ \text { Puerperal convulsions } & 2,692 & 11 \cdot 6 \% \\ \text { Placenta praevia } & 1,308 & 5 \cdot 7 \% \\ \text { Miscarriage and abortion } & 924 & 4 \cdot 0 \% \\ \text { Puerperal mania } & 573 & 2 \cdot 5 \% \\ \text { Phlegmasia dolens } & 456 & 2 \cdot 0 \% \\ \text { Retained placenta } & 354 & 1 \cdot 5 \% \\ \text { Rupture of uterus } & 181 & 0 \cdot 7 \% \\ \text { Extra-uterine foetation } & 54 & 0 \cdot 2 \% \\ \text { Other causes (4 categories) } & 180 & 0 \cdot 8 \%\end{array}$

Total $23,051 \quad 99 \cdot 9 \%$

Deaths from puerperal fever, toxaemia, and haemorrhage

Source: Registrar General's Report for 1876.

$88 \%$
Deaths from sepsis, toxaemia,

No. of \%of

1930

deaths total

$1243 \quad 43 \cdot 5 \%$

Accidents of childbirth

\begin{tabular}{|c|c|c|}
\hline $\begin{array}{l}\text { Puerperal nephritis, } \\
\text { uraemia, nephritis, } \\
\text { and convulsions }\end{array}$ & 467 & $16 \cdot 3 \%$ \\
\hline $\begin{array}{l}\text { Puerperal haemorrhage } \\
\text { Embolism and sudden death } \\
\text { Ectopic gestation } \\
\text { Abortion } \\
\text { Puerperal insanity } \\
\text { Others }\end{array}$ & $\begin{array}{r}348 \\
167 \\
73 \\
65 \\
25 \\
466\end{array}$ & $\begin{array}{r}12 \cdot 2 \% \\
5 \cdot 8 \% \\
2 \cdot 6 \% \\
2 \cdot 3 \% \\
0 \cdot 9 \% \\
16 \cdot 3 \%\end{array}$ \\
\hline Total & 2854 & $99.9 \%$ \\
\hline
\end{tabular}

and haemorrhage

$72 \%$

Source: On the state of public health, 1930 
per 1,000 in 1859 and 70.3 per 1,000 in 1860 (see table 5). ${ }^{66}$ To quote another example, from 1838 to 1860 the average maternal mortality rate at the General Lying-In Hospital in Dublin (The Rotunda), which had varied between seven and eleven per 1,000 in the eighteenth century, rose in the nineteenth to twenty-four per 1,000 between 1854 and 1861 and thirty-four per 1,000 between 1861 and $1868 .{ }^{67}$ In general, it is fair to say that, before about 1880 , it was much safer to be delivered at home than in a lying-in hospital. But there are two factors to be considered in regard to the lying-in hospitals. The first is the significant fall in mortality rates after the introduction of antiseptic and aseptic techniques about $1880 .{ }^{68}$ At Queen Charlotte's Hospital, the average mortality rate during the twenty-three years 1857-1879 was 29.6 per 1,000 deliveries (table 4). During the twenty-three years from 1880 to 1902 , it was 6.0 per 1,000. At the General Lying-In Hospital, maternal mortality fell from a level of 30.8 per 1,000 for $1838-1860$ to 6.2 from $1880-87$ and 0.5 for $1893-1903 .{ }^{69}$ The second factor concerns emergency admissions. Until about the mid-nineteenth century, the population delivered in lying-in hospitals and the population cared for at home by maternity charities were similar, socially and clinically, and there were few transfers from home to hospital in labour. From 1850 onwards, there was a tendency for the lying-in hospitals to admit an increasing number of emergencies from "the district". The emergency cases were often women who had been long in labour, had sometimes been subjected to an unsuccessful forceps delivery, or had bled profusely. Some arrived at hospital in a moribund state. The mortality amongst the emergency admission was very high and influenced the statistics of the hospital. ${ }^{70}$ Thus Queen Charlotte's Hospital undertook deliveries at patients' homes as well as in hospital and used the same antiseptic techniques and staff with the same training. The mortality rate of the patients delivered "on the district" was consistently lower, often about one-fifth of the hospital deliveries, and the main reason was the admission of difficult cases as in-patients. ${ }^{71}$

${ }^{66}$ Williams (1904), op. cit., note 4 above, pp.42-45 and tables XVIII-XXXI.

${ }^{67}$ O'Donel T.D. Browne, The Rotunda Hospital: 1745-1945, Edinburgh, E \& S Livingstone, 1947. A.B. Steele, Maternity hospitals; their mortality, and what should be done with them. (London, Churchill, 1874 ) is a key reference to this subject. In this work the author, a Liverpool obstetrician, shows conclusively that the maternal mortality was unacceptably high in lying-in hospitals throughout Britain. He also shows that a large majority of leading obstetricians of this period knew this and believed without doubt that it was safer for a woman "of the hospital class" to have her baby at home than in a lying-in hospital. "If I read current literature aright the prevalent opinion is, that while Medical and Surgical Hospitals are on their trial, Maternity Hospitals are already condemned." This quotation of Matthews Duncan appears at the opening of this important and valuable pamphlet.

${ }^{60}$ Williams (1904), op. cit., note 4 above, used this as his prime evidence that the failure of the maternal mortality rate to diminish was due to the failure to use antiseptic methods in domiciliary practice.

${ }^{69}$ Ibid. David Hamilton has recently thrown doubt on the belief that the falling rate in deaths after surgery was due to the use of the antiseptic method. He suggests the improvement was probably due to a better-fed and more healthy population of hospital patients. D. Hamilton and M. Lamb, 'Surgeons and surgery', in $\mathrm{O}$. Checkland and $\mathrm{M}$. Lamb (editors), Health care as social history, Aberdeen University Press, 1982, pp. 74-85.

${ }^{70}$ Munro Kerr, op. cit., note 4 above, pp.238-241. At the Glasgow Royal Maternity Hospital the mortality rates were: district cases, 2.4 per 1,000 deliveries; transferred to hospital in labour, 46.2 per 1,000. East End Maternity Hospital, London, 1928-31, mortality rate for cases delivered in the district, 0.7 per 1,000 , booked cases delivered in hospital, 1.2 per 1,000 , emergency admissions, 50 per 1,000 . See esp. table 50, p.259, which shows that in some maternity hospitals in 1929-30 emergency admissions outnumbered booked cases.

${ }^{7}$ Williams (1904), op. cit., note 4 above, tables XVIII and XIX, pp.42-43. 


\section{Irvine Loudon}

In the context of England and Wales as a whole, however, the statistics of hospital delivery had very little effect. In 1890 , only 2,700 deliveries took place in the voluntary hospital sector, representing 0.3 per cent of all births. One per cent took place in poor law hospitals, and 4.6 per cent under the care of the dispensaries and out-patient lying-in charities. ${ }^{72}$ Over ninety per cent were home deliveries attended privately by medical practitioners or midwives, except for the unknown number of unattended births. ${ }^{73}$ The pattern of maternal mortality was essentially that of private domiciliary midwifery, the remainder being too few to influence the national statistics to a noticeable extent. Hospital births were still only fifteen per cent of the total in 1927 , twenty-four per cent in 1933 , and fifty-four per cent in $1946 .{ }^{74}$ The hospital deliveries increased rapidly, and home deliveries fell from 33.2 per cent in 1960 to thirteen per cent in 1970 and 1.2 per cent in $1980 .^{75}$

\section{MATERNAL MORTALITY IN THE POST-REGISTRATION PERIOD}

Before the reasons for the undiminished maternal mortality in the post-registration period can be considered there are two connected questions that need to be answered. First, what were the components of maternal mortality and did they change significantly during this period? Second, do the national statistics reflect the true level of puerperal mortality or were they so distorted by changes in the classification of disease, and the completeness and accuracy of death certification, that a true fall in mortality was obscured by statistical artefact?

\section{Causes of death in childbirth}

Broadly speaking, the relative contribution of various causes to maternal mortality did not change significantly during the period 1850 to 1935 (see table 5). Puerperal sepsis was responsible for about half the total deaths and remained the single most common cause of death until 1937. Ante- and post-natal haemorrhage, and toxaemia were next in importance, accounting in most years for a little over one-quarter of all deaths. Deaths from abortion are considered below, and a variety of other causes accounted for the remainder.

Toxaemia is a duficult cause to assess. ${ }^{76}$ It is still a disorder the cause of which is unknown and which sannot be defined precisely. It is primarily a disease of the young primagravida, while post-partum haemorrhage is most common in older mothers who have borne many children. Thus, between 1915 and 1923, toxaemia deaths (recorded as "puerperal convulsions and nephritis") accounted for thirty-nine per

\footnotetext{
${ }^{72}$ Loc. cit., note 29 above. The calculation is based on the data in appendix 4, p.136.

${ }^{73}$ Ibid. From evidence given to this committee it seems that few women were delivered at home by poor law surgeons. Instead, it was insisted that they should go into poor law hospitals. While this is certainly true in some areas, it is impossible to be certain how general this was.

${ }^{74}$ Maternity in Great Britain. Survey of social and economic aspects of pregnancy and childbirth undertaken by the Joint Committee of the Royal College of Obstetricians and Gynaecologists and the Population Investigation Committee, Oxford University Press, 1948, p. 48ff.

${ }^{75}$ Macfarlane and Mugford, op. cit., note 61 above, fig.7.4, p.158.

${ }^{78}$ On the epidemiology of toxaemia see esp. T.W. Eden, 'Eclampsia', J. Obstet. Gynaec. Br. Empire, 1922, 29 no.3: 386-401; I. McGillivray, 'Some observations on the incidence of pre-eclampsia', ibid., 1958, 65: 536-539; D. Baird, 'Epidemiological aspects of hypertensive pregnancy', Clin. Obstet. Gynaec., 1977, 4: 531-547.
} 


\section{Deaths in childbed}

cent of maternal deaths in the age group 15-20 and 14.8 per cent in the age group $40+$; but the respective rates for deaths from post-partum haemorrhage ("haemorrhage other than placenta praevia") were 4.7 per cent for the 15-20 group and eight per cent for the $40+$ group. ${ }^{77}$ From the late nineteenth century, there were repeated exhortations concerning the early diagnosis and treatment of toxaemia. In fact, there was, and still is, very little that can be done to treat toxaemia apart from induction of labour and delivery. ${ }^{78}$ The apparent fall in the incidence of toxaemia is simply a reflection of the increased use and efficiency of induction of labour; the more mothers were allowed to go past the date of expected delivery, the more cases of toxaemia. There is no evidence that the tendency to develop toxaemia was more common in the past, although it may have been more frequent due to a larger number of cases of post-maturity.

It is commonly believed that deaths from obstructed labour (usually a consequence of contracted pelvis associated with rickets) was a common cause of mortality in the nineteenth century. ${ }^{79}$ It is certain that contracted pelvis was much more common than it is today, and it reached a high peak in Glasgow in 1870-80 following an "epidemic" of rickets there in the mid-nineteenth century, which led to the extensive employment of caesarean section.$^{80}$ But this was exceptional, and caesarean section was rarely employed before the 1930 s.

If there was gross cephalo-pelvic disproportion preventing the head from entering the pelvis, death from ruptured uterus or exhaustion was inevitable unless the condition was dealt with. It could be dealt with by caesarean section, but, as seen above, this was so uncommon, except in a few areas, that deaths associated with it can be discounted. The rest would have been relieved either by craniotomy or, in minor degrees of disproportion, by the use of the long forceps. Deaths in these cases could result from injuries or infection associated with these dangerous manoeuvres.

Table 6 is based on the detailed report of the very large number of cases delivered under the care of the Royal Maternity Charity in the 1830s and 1840s. There, if anywhere, deaths from obstructed labour should be obvious. Yet the deaths associated with ruptured uterus, exhaustion, and the use of instruments amounted to eighteen out of 126 deaths compared to fifty-six deaths from haemorrhage and thirty-four from sepsis. ${ }^{81}$ Copeman, in 1874 , reviewed his cases, which were all attended "in consultation practice, and are therefore of an unusually severe or complicated character and do not include any attended alone as ordinary cases". Out of 216 cases attended as a consultant, eighteen died but only three deaths could be attributed to obstructed labour. Craniotomy was carried out in fourteen cases with only one death; forceps were used in six cases with no deaths, and ruptured uterus

\footnotetext{
${ }^{77}$ Munro Kerr, op. cit., note 4 above, table IV, p.19.

${ }^{78}$ The usual treatment of toxaemia is rest; it was seldom helpful advice for working-class mothers in times of social and economic deprivation.

${ }^{\text {to }}$ Rickets could cause not just one but a variety of deformities of the pelvic inlet, all tending to make it difficult or impossible for foetal head to enter the pelivs. See J. Chassar Moir, Munro Kerr's operative obstetrics, 6th ed., London, Baillière, Tindall \& Cox, 1956,

${ }^{30}$ Derek A. Dow, The Rotten Row. The history of the Glasgow Royal Maternity Hospital, Carnforth, Parthenon Press, 1984, ch.5, pp.59-70.

${ }^{81}$ F.H. Ramsbotham, 'Tabular view of the cases admitted to the Eastern District of the Royal Maternity Charity', Lond. med. Gaz., 1843-44, new series 2: 619-623.
} 


\section{Irvine Loudon}

occurred on two occasions, both fatal. ${ }^{82}$ Robert Dunn, a general practitioner, kept very careful record of his work in the mid-nineteenth century. Out of 4,049 cases there were twenty-seven deaths, two after craniotomy, none after forceps or due to ruptured uterus or exhaustion.$^{83}$ Obstetric texts of the nineteenth century and early years of this century dealt at length with obstructed labour because it was a terrifying complication and difficult to deal with, giving the false impression that it was very common. The statistics confirm that obstructed labour often carried a high mortality, but that deaths from this cause were much less common than from the causes noted above. Most cases of puerperal sepsis occurred after normal labours in which no interference had taken place.

TABLE 6. AN ACCOUNT OF THE STILLBIRTHS AND MATERNAL DEATHS RECORDED BY THE ROYAL MATERNITY CHARITY IN LONDON BETWEEEN 1831 AND 1843.

Total number of deliveries children born living

children stillborn

Total maternal deaths associated deaths puerperal deaths
35,743

33,868

$2,263(6 \cdot 2 \%)$

$166(4 \cdot 6 / 1000$ del. $)$

40

$126(3 \cdot 5 / 1000$ del. $)$

$\begin{array}{lr}\text { Associated deaths } & \\ \text { phthisis } & 15 \\ \text { pneumonia } & 6 \\ \text { typhus } & 6 \\ \text { Asiatic cholera } & 4 \\ \text { other diseases } & 9 \\ & \\ \text { Puerperal deaths } & 126 \\ \text { haemorrhage } & 56 \\ \text { peritonitis, hysteritis, pelvic inflammation, and common fever } & 34 \\ \text { other } & 36\end{array}$

of which all which might have been associated with obstructed labour were:

$\begin{array}{lr}\text { deaths due to ruptured uterus } & 8 \\ \text { deaths after craniotomy } & 6 \\ \text { deaths after forceps } & 3 \\ \text { 'exhausted under lingering labour' } & 1\end{array}$

Total in this group

Source: F.H. Ramsbotham, 'The Eastern District of the Royal Maternity Charity', Lond. Med. Gaz., 1843-44, new series 2: 619-625.

Maternal mortality statistics: accurate or artefact?

Death certification was voluntary until 1874 , and certification of maternal deaths was imperfect until 1881 when Farr introduced an inquiry into all deaths in women of

${ }^{82}$ E. Copeman, 'Statistical and practical remarks on consultation midwifery in private practice', Trans. Obstet. Soc. Lond., 1874, 16: 103-110. Of the craniotomy case that died, he remarked that she was "almost in articulo mortis when the operation was resorted to as a last resource. There can be but little doubt that craniotomy is generally a safe operation if not too long delayed .... I must say a word about the crotchet in order to denounce it as a more or less dangerous instrument, and very often ineffective ...."

${ }^{83} R$. Dunn, 'On the statistics of midwifery from the records of private practice', ibid., 1859-60, 1: 279-297. 


\section{Deaths in childbed}

childbearing age where childbirth was not mentioned, but a puerperal cause was suspected - e.g., deaths from "peritonitis" or "pyaemia". To a certain degree, therefore, under-reporting of puerperal mortality occurred before the $1880 \mathrm{~s}$. However, there was a tendency to include associated deaths in the total, especially in private reports, but also in the national figures until 1864, when Farr stated that these should be "referred to the fatal disease in question" ${ }^{84}$ Moreover, there was no explicit rule at first on the official length of the "lying-in" period for the purposes of death registration. Some late deaths were included until the convention of using one month (it is now six weeks) was adopted. In 1911, the introduction of the International List of Causes of Death (ILCD) led to deaths in the puerperium due to "nephritis and albuminuria" being included as maternal deaths. This made little difference to the statistics because deaths from eclampsia were already included as "puerperal convulsions". ${ }^{85}$ In 1926, puerperal pyrexia was defined as a "fever of $100 \cdot 4^{\circ} \mathrm{F}$ over a period of 24 or more hours during the three weeks after childbirth". In 1927, as noted above, stillbirth registration was introduced; since this increased the denominator from "live" to "total" births, this tended to reduce the maternal mortality rate. Taken together, these factors undoubtedly produced some distortion of true puerperal mortality, but only to a slight degree. The question of deaths from abortion, the extent to which these were hidden and the possible effect on puerperal mortality is, however, complicated and a matter for debate.

\section{The influence of abortion deaths on the maternal mortality rate}

Deaths from abortion were always included in the national figures and remained approximately the same proportion to the total. In 1929, following the fourth revision of the ILCD, deaths from abortion were divided into two groups (nos. 140 and 141), septic and without sepsis. Spontaneous abortion deaths could be septic but sepsis was more likely to occur after induced or criminal abortion. When the latter was recognized and came before a coroner's jury, the death was recorded amongst deaths from violence and excluded from maternal death rates. Although the number of reported deaths from criminal abortion increased through the first three decades of the twentieth century, they were always a small minority of all such deaths and in total were too few to affect the maternal mortality rate materially even if they had been included. ${ }^{88}$ The important question, therefore, concerns the possible large-scale increase in maternal deaths from undetected, or unproven, criminal abortion. Shorter believes they had a major distorting influence on the national statistics from 1880 to 1930 . "So overwhelming was the torrent of abortion fatalities [in the 1930s] that many ended up in general 'puerperal sepsis' put there by local doctors anxious to circumvent scandal or to avoid offending the family. ${ }^{87}$ He attaches such importance

\footnotetext{
${ }^{84}$ Registrar General's Report for 1864, pp.192 and 205. In the report for 1841, there is a long and important account of current views on the contagious nature of puerperal fever, including letters from various practitioners. But the opening section of this account (p.380) seems to show quite clearly that during this period, associated deaths were being included in the statistics of maternal mortality.

${ }^{85}$ Macfarlane and Mugford, op. cit., note 61 above, fig. 10.1, p.197.

${ }^{86}$ They amounted to about two to three per cent of all maternal deaths. See Munro Kerr, op. cit., note 4 above.

${ }^{87}$ Shorter, op. cit., note 63 above, chs. $5,6,8$. Shorter tends to draw on sources from a number of different countries in order to make general statements on abortion and sepsis in midwifery. The difficulties of such an approach are discussed briefly at the end of this paper.
} 


\section{Irvine Loudon}

to the scale on which this occurred (an increasing scale from 1880 to the 1930 s) that he dismisses the undiminished maternal mortality as a myth, asserting that there was a substantial fall in the full-term maternal mortality rate between 1880 and the 1930 s and that the abortion deaths were hidden in "puerperal sepsis". If Shorter is right, the fall in full-term deaths should be evident in "accidents of childbirth" as the standard of obstetrics improved, while puerperal sepsis deaths should have increased to maintain the overall level of maternal mortality. But this did not occur.

PUERPERAL SEPSIS DEATHS AS A PERCENTAGE OF TOTAL MATERNAL DEATHS

$\begin{array}{llllll}1880-85 & 57 \% & 1906-10 & 42 \% & 1931 & 40 \% \\ 1886-90 & 53 \% & 1911-15 & 39 \% & 1932 & 38 \% \\ 1891-95 & 46 \% & 1916-20 & 41 \% & 1933 & 40 \% \\ 1896-1900 & 43 \% & 1921-25 & 40 \% & 1934 & 44 \% \\ 1901-05 & 45 \% & 1926-30 & 45 \% & 1935 & 41 \%\end{array}$

But it may be argued that the fall in full-term maternal deaths was confined to puerperal sepsis where, to an increasing extent, deaths from septic abortion replaced full-term deaths from sepsis. To have caused a substantial fall in maternal mortality, this would have required a very large fall indeed in full-term puerperal sepsis. Such a decline would have removed full-term sepsis from its place as the most common cause of death. All the evidence from the 1920s and 1930s contradicts this assertion. For example, when the Medical Research Council in 1929-30 became concerned with the subject of maternal mortality it identified full-term puerperal sepsis as much the most important cause of death and directed its research entirely into the cause, prevention, and treatment of this complication. ${ }^{88}$

Shorter does not quantify the extent of the alleged fall in full-term maternal mortality, but alleges it was "substantial" and refers the reader to a figure of twenty-one as the percentage of all septic deaths due to induced abortion in Britain in the 1930s. ${ }^{89}$ Even if allowance is made for these septic abortion deaths, it makes relatively little difference to total mortality. If deaths from septic abortion are subtracted from the total maternal mortality rate, a rate of 4.6 in the late nineteenth century would be reduced to 4.48 and a rate of 4.6 in the late 1920 s or early $1930 \mathrm{~s}$ would be reduced to $4.21 .^{90}$ Thus, allowance for hidden deaths from induced abortion would at most produce a slight fall, not a substantial one. However, the most important reason for rejecting the hypothesis that there was a substantial fall in

\footnotetext{
${ }^{*}$ Medical Research Council Annual Reports from 1929-30, and the archives of the Council, file 2060.

${ }^{80}$ The source of this value of twenty-one per cent as the percentage of septic deaths due to abortion is the Statistical Review for 1929 quoted in Munro Kerr, op. cit., note 4 above, pp. 132-133. The annual rates were $192620.0 \%, 192721.0 \%, 192818.9 \%, 192920.6 \%, 193024.1 \%$.

${ }^{80} \mathrm{This}$ calculation is based on the assumption that twenty-one per cent of total septic maternal deaths in the late 1920 s and early 1930 s were due to abortion when total deaths from sepsis were between forty and forty-five per cent of total maternal mortality. Induced abortion also occurred in the nineteenth century and was also concealed, but $I$ have assumed a value of five per cent for the percentage of puerperal sepsis deaths in the 1880 s and 1890 s due to abortion when puerperal sepsis accounted for about fifty per cent of all deaths.
} 


\section{Deaths in childbed}

full-term maternal mortality, hidden by septic abortion deaths, is the view of medical practitioners working in this period.

Janet Campbell and her colleagues in 1924 and $1932,{ }^{91}$ Munro Kerr in $1933,{ }^{92}$ and Douglas and McKinley in $1935^{93}$ were all aware of the problem of fatalities due to induced abortion and to the fact that they were increasing. None, however, believed these deaths disguised a substantial fall in full-term deaths from puerperal sepsis. Munro Kerr in 1933 dealt with this in detail. ${ }^{94} \mathrm{He}$ concluded that deaths from abortion, including hidden deaths, had not increased to such an extent as to affect seriously the maternal mortality rate as a whole; he believed they might in the future, and had already done so in some countries, notably in Germany; but not in Britain in 1933.

The evidence therefore suggests that, from the mid-nineteenth century until the mid-1930s, there was no substantial or sustained fall in full-term maternal mortality in England and Wales, or in Scotland.

\section{The causes of the undiminished maternal mortality before 1935}

A persistent high maternal mortality, or a higher rate in one part of a country than the country as a whole is likely to be due to one or both of two groups of factors. Poor obstetric care, judged by the standards of the time, due to poor education or poor application in practice; or, second, to social and economic deprivation. Social and economic deprivation would operate through its effect on the health of the mother before, during, and immediately after pregnancy and labour. Common sense suggests that poor health due to poor nutrition, housing, and sanitation must lower resistance to most, if not all, the causes of maternal deaths. High maternal mortality, in short, may be due to bad midwives, bad medical practitioners, or unhealthy mothers, and these factors, acting in concert, are often difficult to disentangle. Since the evidence of the relative importance of these factors is sometimes complex, it might be helpful at this stage to anticipate my final conclusion, because it may be regarded as an unexpected one. It is that maternal mortality appears to have been remarkably resistant to the ill-effects of social and economic deprivation, but remarkably sensitive to the good and the bad effects of medical intervention. Not all the evidence points this way, but most of it does.

To start with, the pattern of maternal mortality since 1850 is in stark contrast to the pattern of deaths from all causes in women of childbearing age (fig.3); and also to the infant mortality rate (fig.4). The death rate from all causes diminished steadily from 1838 , and the infant mortality rate, after remaining level from 1838 to 1900 , also fell substantially and steadily until the present. It is generally agreed in both instances that the decline in mortality from 1850 to 1930 had little if anything to do with medical intervention and much to do with rising standards of living. The pattern of maternal mortality for England and Wales as a whole (and also for Scotland)

\footnotetext{
${ }^{91}$ Campbell et al. (1932), op. cit., note 4 above.

${ }^{92}$ Munro Kerr, op. cit., note 4 above.

${ }^{93}$ Douglas and McKinley, op. cit., note 2 above.

${ }^{94}$ Munro Kerr, op. cit., note 4 above. Chapter 5 deals with abortion in careful detail.
} 
therefore suggests that changes in the standard of living, which had a marked effect on health in other respects, had little influence on deaths from childbirth.

This, however, appears to be contradicted when regional differences are examined, for there appears to be a correlation between regions of high mortality and regions traditionally associated with deprivation and poverty. Williams observed in the late nineteenth century that if a line was drawn from the Severn to the Humber (fig.6) nearly all the counties to the north and west of the line had a higher than average maternal mortality, nearly all to the south and east a lower than average. ${ }^{95}$ What is more, this pattern of regional difference remained largely unaltered from the 1860 s until 1935 (table 7). It was surprising how clear-cut this difference remained. In 1926 , the maternal mortality in Wales was 4.92 per 1,000 deliveries, 4.75 in the north of England, 3.78 in the midlands, and 3.43 in the south. ${ }^{96}$ In 1929, when the mortality for England and Wales was 4.33 it was 11.46 in Radnorshire, 10.33 in Wigan, 8.04 in Bolton, 2.49 in Oxfordshire. In Bootle, strangely, it was $1.80 .^{97}$

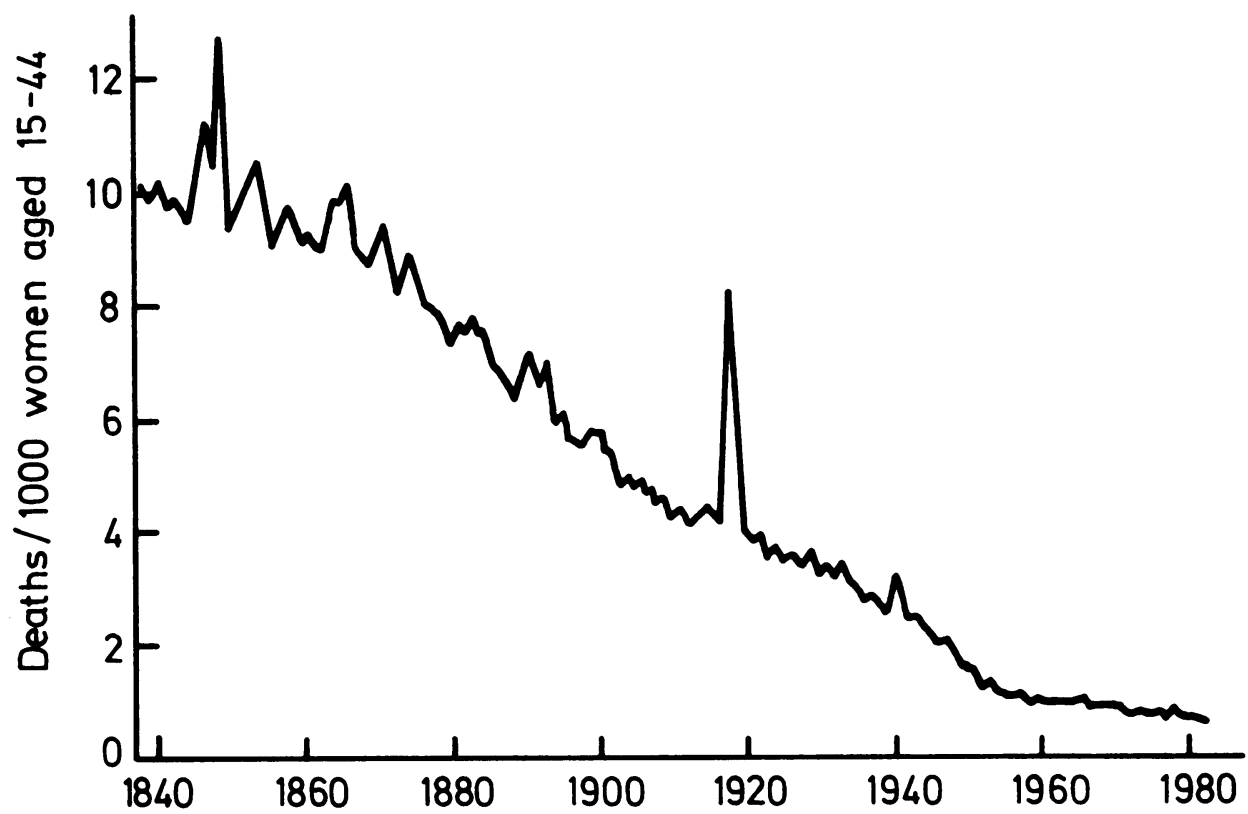

Fig 3

Death rates from all causes in women aged 15-44, England and Wales, $1838-1982$ (source:OPCS Mortality statistics)

${ }^{95}$ Williams (1895-96), op. cit., note 2 above.

${ }^{96}$ Munro Kerr, op. cit., note 4 above, p.12.

${ }^{97}$ On the State of the Public Health for 1929. Although it changed in detail, the general picture here described remained remarkably constant year after year, with Wales and the industrial north showing the highest maternal mortality rates. 


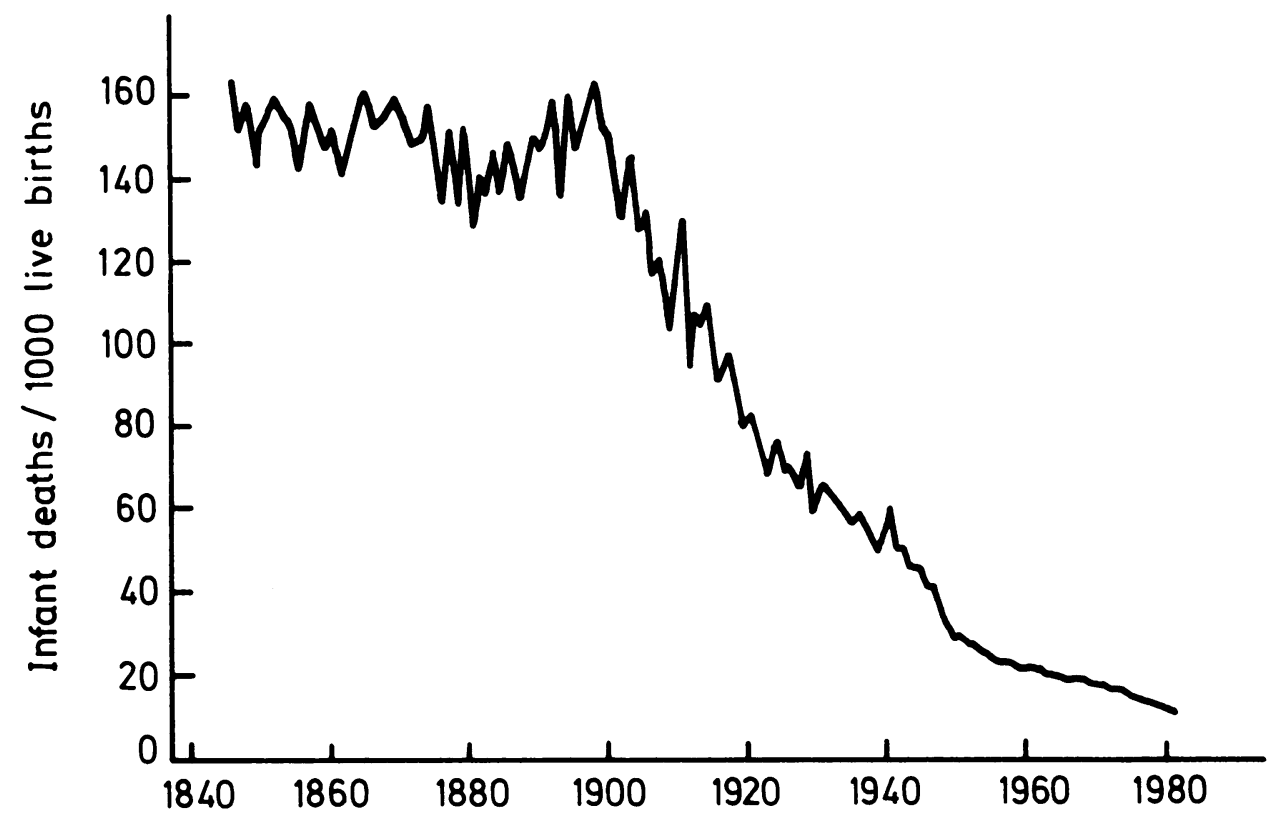

Fig. 4 .

Infant mortality rates, England and Wales 1846-1928.

(source: OPCS Mortality statistics)

Dame Janet Campbell, in 1935, assessed this regional difference as one due to a high maternal mortality in heavily industrial and remote rural areas. ${ }^{98}$ The feature that these two types of region would seem to have in common is poor socio-economic conditions. Williams, a medical officer of health with a lively appreciation of the effects of poor nutrition and living conditions on health, nevertheless rejected this as the explanation of the persistent high mortality in the Welsh mining valleys. At the beginning of the twentieth century, the miners, he stated, were relatively well off, "wages are high, and nourishing food plentiful". ${ }^{99}$ Poor housing might play a part, but the main reason for maternal deaths was that south Wales was cursed with ignorant midwives who spread puerperal fever from house to house. ${ }^{100}$ To the observers of regional differences the cause was far from obvious. It might be poverty, overwork, and poor housing that afflicted the poor of the north and west, but equally it might be that these were the least attractive regions for medical practice and they had more than their fair share of inefficient general practitioners and ignorant, dirty midwives. This conclusion was confirmed, at least in part, by Janet Campbell and her colleagues in 1932, when they conducted an examination into causes of maternal

\footnotetext{
${ }^{98}$ Campbell (1935), op. cit., note 4 above, who pointed out that Holland's good record in obstetrics was associated with an absence of any large heavily industrialized areas and remote rural ones, which had the conspicuously high mortality rates in England and Wales.

${ }^{99}$ Williams (1904), op. cit., note 4 above, p.33.

${ }^{100}$ Ibid.
} 


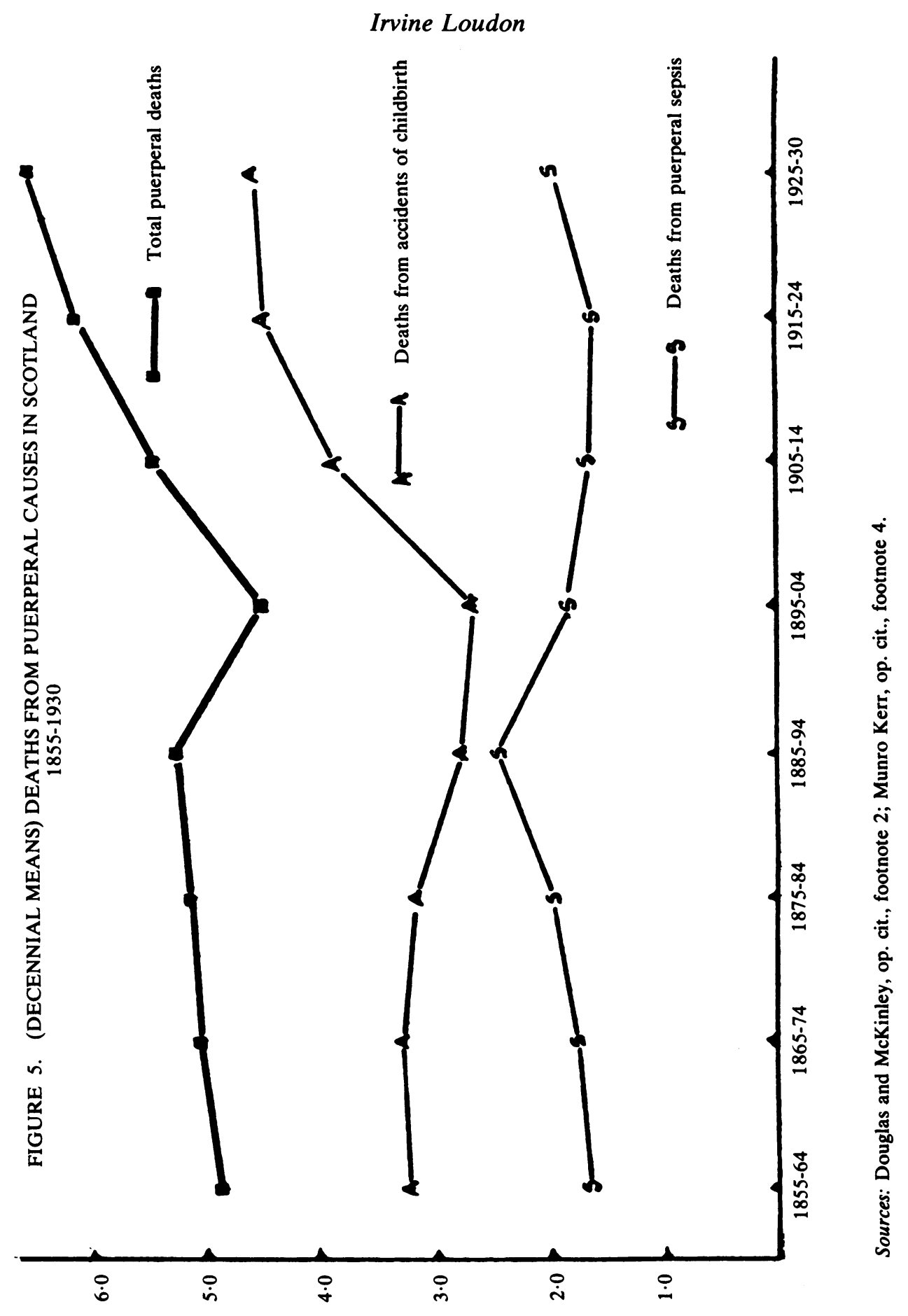

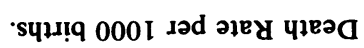




\section{Deaths in childbed}

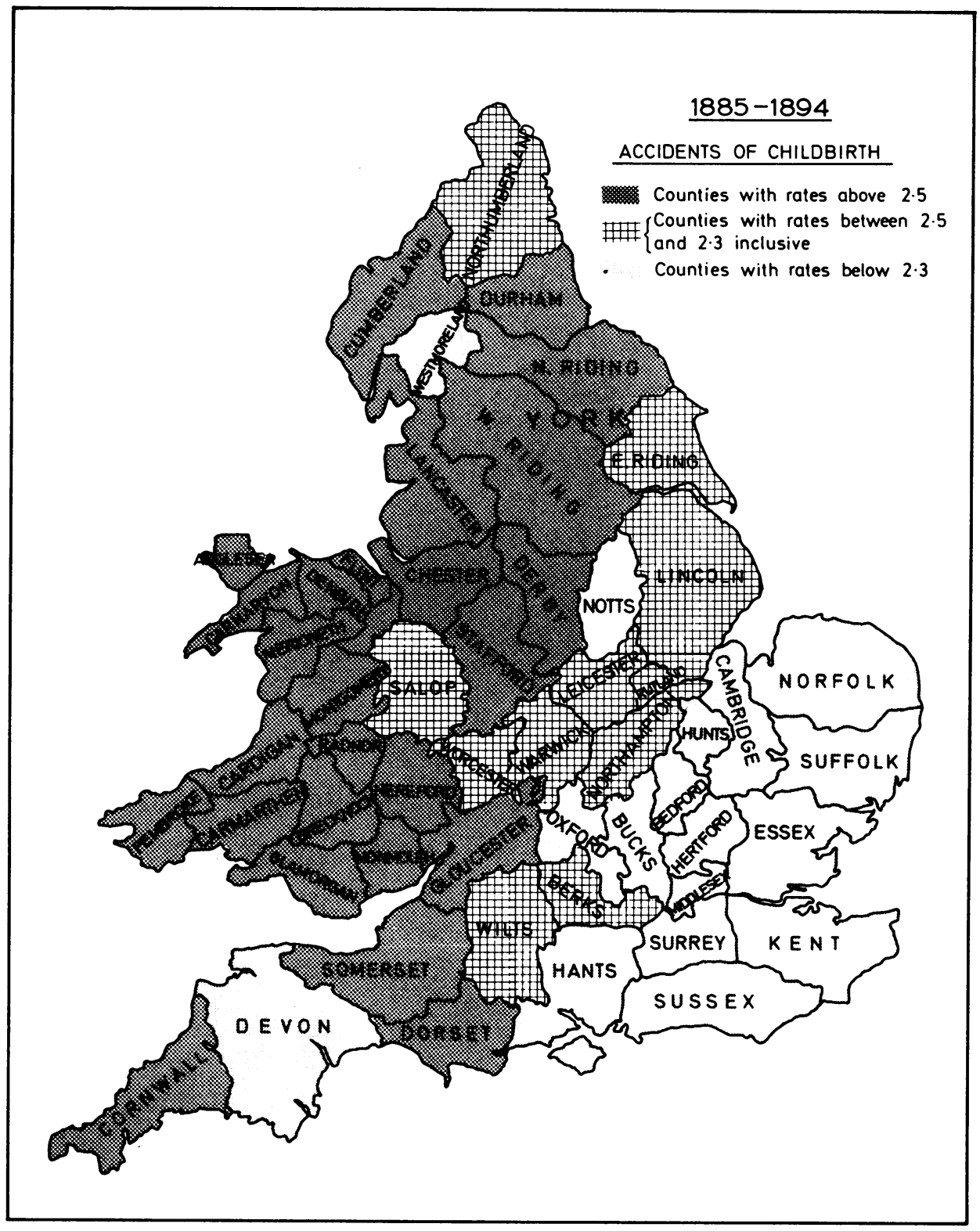

FIGURE 6(a). ENGLAND AND WALES. DEATHS FROM ACCIDENTS OF CHILDBIRTH 1885-94, EXPRESSED AS DEATHS PER 1000 BIRTHS.

Source: Williams (1895-6), op. cit., footnote 4 . 


\section{Irvine Loudon}

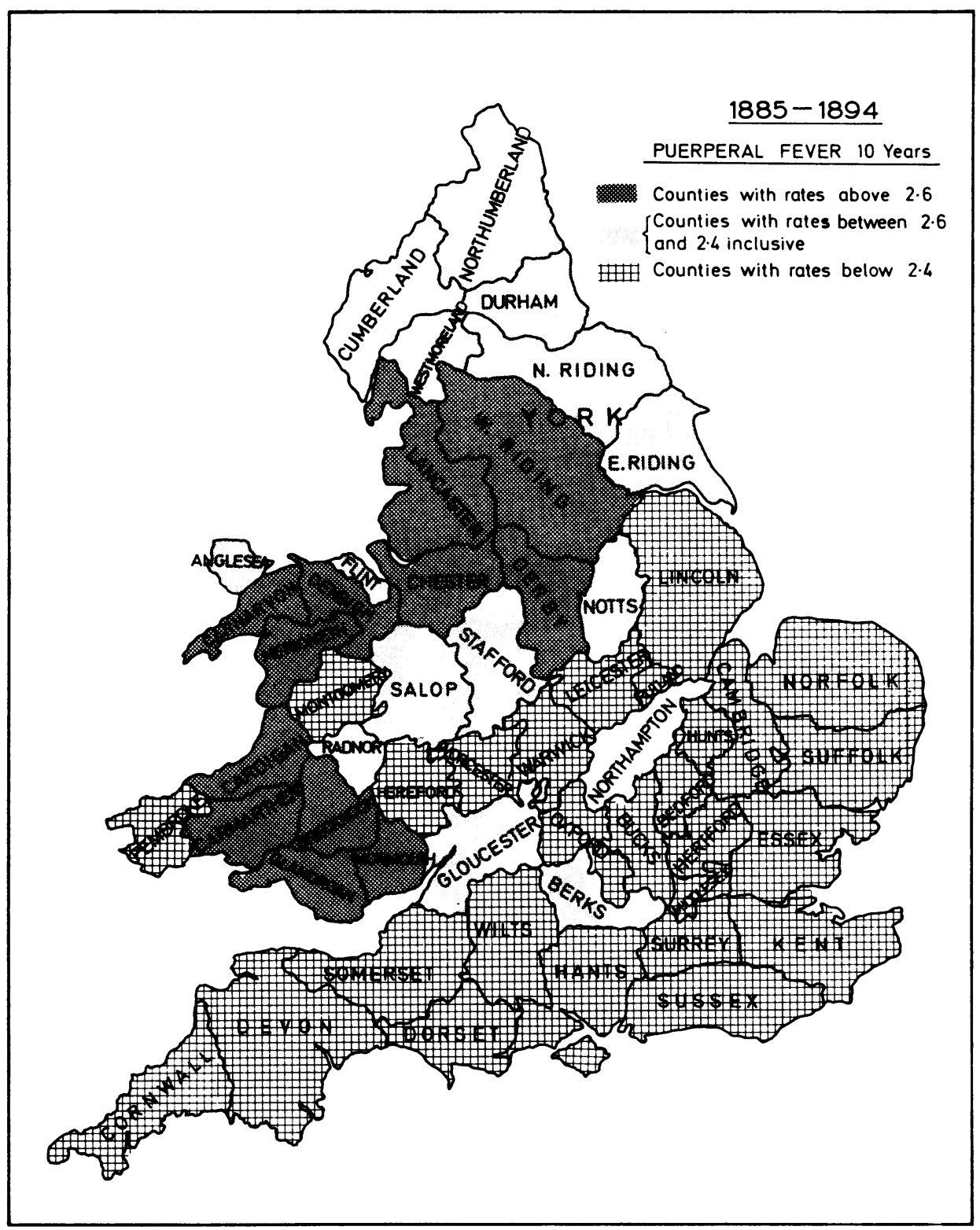

FIGURE 6(b). ENGLAND AND WALES, DEATHS FROM PUERPERAL FEVER 1885-94, EXPRESSED AS DEATHS PER 1000 BIRTHS.

Source: Williams (1895-6), op. cit., footnote 4. 
TABLE 7. MATERNAL MORTALITY RATES IN COUNTIES AND COUNTY BOROUGHS IN ENGLAND IN 1923; SELECTED COUNTIES, AND MORTALITY RATES IN CERTAIN SELECTED METROPOLITAN BOROUGHS, 1919-1922.

\begin{tabular}{|c|c|c|c|}
\hline \multirow[b]{2}{*}{$\begin{array}{l}\text { County boroughs and } \\
\text { counties with the } \\
\text { highest rate }\end{array}$} & \multicolumn{3}{|c|}{ Deaths from } \\
\hline & $\begin{array}{l}\text { Puerperal } \\
\text { fever }\end{array}$ & $\begin{array}{l}\text { Accidents } \\
\text { of } \\
\text { childbirth }\end{array}$ & $\begin{array}{c}\text { Total } \\
\text { materna } \\
\text { deaths }\end{array}$ \\
\hline $\begin{array}{l}\text { Halifax } \\
\text { Blackpool } \\
\text { Rochdale } \\
\text { Huddersfield } \\
\text { Swansea }\end{array}$ & $\begin{array}{l}2 \cdot 51 \\
2 \cdot 83 \\
1 \cdot 80 \\
1 \cdot 61 \\
2 \cdot 29\end{array}$ & $\begin{array}{l}5 \cdot 31 \\
4 \cdot 72 \\
5 \cdot 25 \\
5 \cdot 09 \\
4 \cdot 30\end{array}$ & $\begin{array}{l}7 \cdot 82 \\
7 \cdot 55 \\
7 \cdot 05 \\
6 \cdot 70 \\
6 \cdot 59\end{array}$ \\
\hline \multicolumn{4}{|l|}{$\begin{array}{l}\text { County boroughs } \\
\text { counties with the } \\
\text { lowest rate }\end{array}$} \\
\hline $\begin{array}{l}\text { West Ham } \\
\text { Worcester } \\
\text { East Ham } \\
\text { Reading } \\
\text { Northampton }\end{array}$ & $\begin{array}{l}0.79 \\
0.51 \\
1 \cdot 35 \\
1.20 \\
1.40\end{array}$ & $\begin{array}{l}1.24 \\
1.53 \\
0.95 \\
1.47 \\
1.40\end{array}$ & $\begin{array}{l}2 \cdot 03 \\
2 \cdot 04 \\
2 \cdot 30 \\
2 \cdot 67 \\
2 \cdot 80\end{array}$ \\
\hline \multicolumn{4}{|l|}{$\begin{array}{l}\text { Certain selected } \\
\text { metropolitan boroughs }\end{array}$} \\
\hline $\begin{array}{l}\text { Bermondsey } \\
\text { Chelsea } \\
\text { Hampstead } \\
\text { Kensington } \\
\text { Poplar } \\
\text { Shoreditch } \\
\text { Stoke Newington } \\
\text { Westminster }\end{array}$ & $\begin{array}{l}1 \cdot 26 \\
1.78 \\
1 \cdot 87 \\
1 \cdot 89 \\
1 \cdot 15 \\
1.48 \\
2 \cdot 91 \\
1 \cdot 70\end{array}$ & $\begin{array}{l}1 \cdot 64 \\
4 \cdot 01 \\
1 \cdot 31 \\
2 \cdot 42 \\
1 \cdot 75 \\
1 \cdot 07 \\
2 \cdot 18 \\
2 \cdot 49\end{array}$ & $\begin{array}{l}2 \cdot 90 \\
5 \cdot 79 \\
3 \cdot 18 \\
4 \cdot 31 \\
2 \cdot 90 \\
2 \cdot 55 \\
5 \cdot 09 \\
4 \cdot 19\end{array}$ \\
\hline
\end{tabular}

Source: Campbell (1924), op. cit., footnote 40.

deaths in two areas of high mortality, Lancashire and Wales. ${ }^{101}$ In Wales, it was concluded that poor obstetric facilities were mainly to blame for the excess deaths. In Lancashire, while rickets and other disorders of nutrition played a part, they were not considered factors of first importance. It was difficult to separate the effects of poor nutrition and poor obstetric care, but the latter seemed to be the more important.

More positive evidence of the lack of importance of social and economic factors comes from a finding so unusual that it has been called the "reverse" relationship between social class and maternal mortality, for it shows that social classes I and II often suffered a higher mortality rate than social classes IV and V. This difference was usually confined to deaths from puerperal sepsis. It is interesting that Robert Bland made a similar observation in 1781:

${ }^{101}$ Campbell et al. (1932), op. cit., note 4 above. 


\section{Irvine Loudon}

I am inclined to believe that the lower sort of people recover more certainly after parturition than persons in higher stations of life; at least they are less subject to the puerperal fever, which is so fatal if not checked at the first attack; and which, if not caused, is certainly nourished and its malignancy increased by great fires, close rooms, warm septic diet, and costiveness. But the apartments of the poor are generally so crazy, that without opening doors or windows, to which they are sufficiently averse, the air pours in upon them from all sides. ${ }^{102}$

Such a conclusion was not as surprising then as it is today. The naturalistic philosophies of the eighteenth century suggested that the poor were closer to the "noble savage" of nature and therefore efficiently prolific in their breeding, while the effete and pampered rich were prone to barrenness and the complications of childbirth. ${ }^{103}$ One might be tempted to dismiss this as impressionistic were it not for subsequent evidence. For example, the mortality rates achieved amongst the poor of London by the dispensaries and out-patient lying-in charities, which were substantially lower than the national rates, suggest that poverty was not an important factor in maternal mortality. But it was Cullingworth who showed in 1898 that if one examined the districts of London in terms of deaths from puerperal sepsis, contrary to expectation, the poorer areas had the lower mortality. Hampstead and Islington had high rates, Rotherhithe and Bermondsey low ones. Kensington and Chelsea had higher rates than Lambeth, Whitechapel, St George's in the East, and Shoreditch. ${ }^{104}$ The inference, that high mortality rates were associated with a high percentage of deliveries by medical practitioners, low rates with deliveries by midwives, was suggested but not pursued when it was shown that there was even stronger evidence of such an association for Leeds and Glasgow. ${ }^{105}$ In 1930-32, further confirmation of this tendency was shown by analysis of maternal mortality according to social class of husband in England and Wales (table 8). Contrary to so many indices of health, this showed clearly that maternal mortality decreased from social classes I and II to social class V. This was especially noticeable for puerperal sepsis but not for puerperal haemorrhage. The greater risk of sepsis through delivery at home by a general practitioner seems to have been the main but not the only factor in the higher maternal mortality of the higher social classes. What was the explanation?

The likelihood that medical practitioners could carry infection from a fever case to a maternity case had been recognized long before Semmelweis's classical work on the contagious nature of puerperal fever in $1843-46 .{ }^{106}$ But the association of a high rate of fever with medical attendance was probably not so much due to case-to-case

\footnotetext{
${ }^{102}$ Bland, op. cit., note 52 above.

${ }^{103} \mathrm{~J} . S$. Lewis, 'Maternal health in the English aristocracy: myths and realities, 1790-1840', J. soc. Hist., 1983, 17(1): 97-114.

${ }^{104}$ Cullingworth, op. cit., note 4 above.

${ }^{105}$ Munro Kerr, op. cit., note 4 above. In Leeds from 1920 to 1929 , the maternal mortality in the city as a whole was 4.49 per 1,000 births. In the middle-class areas it was 5.93 and in the working-class areas 3.01 . An investigation in Aberdeen through the 1920s failed to show any association between maternal mortality and poor housing or overcrowding. The worst areas for housing showed no higher rates of maternal mortality than the best. Medical Research Council Archives, file 2060.

${ }^{108}$ See esp. Hirsch, op. cit., note 63 above, chapter on puerperal fever; and A.W.W. Lea, Puerperal infection, London, Oxford Medical Publications, 1910. See also William Farr, 'Childbirth fatal by contagion', in the 5th Annual Report of the Registrar General for 1841, 1843, pp.384-396. J.G. Adami, Charles White of Manchester (1728-1813) and the arrest of puerperal fever, London, Hodder \& Stoughton, 1922, brings out the advances due to simple cleanliness well before Semmelweis's publications.
} 
TABLE 8. MORTALITY OF MARRIED WOMEN ACCORDING TO THE SOCIAL CLASS OF HUSBAND, ENGLAND AND WALES, 1930-32.

\begin{tabular}{lccccc}
\multicolumn{1}{c}{$\begin{array}{c}\text { Cause of } \\
\text { death }\end{array}$} & $\begin{array}{c}\text { All married } \\
\text { women }\end{array}$ & $\begin{array}{c}\text { Class I \& II } \\
\text { professional } \\
\text { and managerial }\end{array}$ & $\begin{array}{c}\text { Class III } \\
\text { skilled } \\
\text { workers }\end{array}$ & $\begin{array}{c}\text { Class IV } \\
\text { semi-skilled }\end{array}$ & $\begin{array}{c}\text { Class V } \\
\text { unskilled }\end{array}$ \\
$\begin{array}{l}\text { All causes } \\
\text { Total, excluding }\end{array}$ & 4.13 & 4.44 & 4.11 & 4.16 & 3.89 \\
$\quad$ abortion & 3.57 & 3.94 & 3.55 & 3.60 & 3.32 \\
$\begin{array}{l}\text { Puerperal sepsis } \\
\text { Puerperal haemorrhage }\end{array}$ & 1.29 & 1.45 & 1.33 & 1.21 & 1.16 \\
Toxaemia & 0.49 & 0.50 & 0.44 & 0.48 & 0.60 \\
& 0.79 & 0.81 & 0.81 & 0.84 & 0.68
\end{tabular}

Source: J.M. Munro Kerr, R.W. Johnstone, and M.H. Phillips (editors), Historical review of British obstetrics and gynaecology 1800-1950, London, E. \& S. Livingstone, 1954, table 9, ch.29.

spread as to the greater tendency of medical men to carry out vaginal examinations, use forceps, and - compared to midwives - be more impatient. ${ }^{107}$

This "reverse" social class/maternal mortality relationship was, by implication, a serious criticism of the standard of care in general-practitioner obstetrics. Milne Murray roundly accused general practitioners of the misuse of anaesthesia and of "the ridiculous parody which, in many practitioners' hands, stands for the use of antisepsis". ${ }^{108}$ Unnecessary interference was a recurrent accusation and in some areas at least appears to have been true. Andrew Topping in 1936, whose evidence is considered later, described the conduct of some general-practitioner obstetricians as "nothing short of murder". ${ }^{109}$ Dr Cameron of Glasgow informed the Select Committee on Midwives' Registration (1892) that "a chapter of horrors might easily be written upon mismanagement of labour, in which only the mystic letters appended to the operator's name protected him from prosecution". ${ }^{110}$ But the most telling evidence comes from a report of deliveries in Wales. ${ }^{111}$ In cases in which the midwife was booked to attend - and these were on the whole the poorest sections of the community - the forceps rate was three to five per cent. But in cases in which the general practitioner was retained, an excessively high forceps rate was often recorded, as this table shows:

FORCEPS DELIVERIES AS A PERCENTAGE OF TOTAL DELIVERIES IN CASES “BOOKED” BY A GENERAL PRACTITIONER, WALES, 1929-1931

$\begin{array}{llll}\text { Breconshire (1929) } & 5 \cdot 48 \% & \text { Bridgend Urban Dist. Council (1931) } & 42 \% \\ \text { Caernarvonshire (1929) } & 30 \% & \text { Penybont (1931) } & 50 \cdot 7 \% \\ \text { Carmarthenshire (1930) } & 55 \cdot 8 \% & \text { Port Talbot (1931) } & 19 \cdot 7 \% \\ \text { Denbighshire (1931) } & 32 \cdot 9 \% & \text { Neath Borough Council (1930), (1931), } & 20 \% \\ \text { Flintshire (1930) } & 38 \cdot 9 \% & \text { Rhondda Urban D.C. (1920) } & 7 \cdot 9 \%\end{array}$

Source: Jones, op. cit., note 111, table F, p.81.

\footnotetext{
${ }^{107}$ Loc. cit., note 29 above, Q.327-336, see also Lewis, op. cit., note 54 above, notes 92 and 119 . The confidential inquiry into maternal deaths in 1929 showed that in deaths from puerperal fever transmission from one patient to another was uncommon. Most cases were isolated cases. Out of 616 deaths from sepsis, forty-eight per cent followed a normal labour, forty-four per cent followed a complicated labour, and eight per cent followed a forceps delivery in an otherwise normal labour. Interim Report of Departmental Committee on Maternal Mortality and Morbidity, London, Ministry of Health, 1930, chapter 2.
} 


\section{Irvine Loudon}

The author's comment that "forceps are applied unnecessarily often owing to the multiple calls of general practice and the entreaties of the patient" is mild in the face of evidence of such blatantly unnecessary interference. The contrast with the ultra-conservatism of early- and mid-nineteenth-century general practitioners is striking, and it is a nice question whether the inexperience in the use of forceps of the earlier practitioners was more or less dangerous than the unnecessary use of forceps by their more experienced successors in the 1920 s and 1930 s.

Those who believed that poverty and malnutrition were an important contributory cause of maternal mortality were relatively few compared to those who saw the problem entirely in terms of poor clinical care. Nevertheless, the social and economic dimension was not ignored. Williams in 1904 was sensitive to this aspect, and a fellow medical officer of health, observing the high mortality in Wales, suggested in 1937 that it was more likely to be cured by a herd of cows than a herd of specialists. ${ }^{112}$ Janet Campbell, at the Ministry of Health in the 1920 s and early 1930 s, was especially concerned with the social as well as the medical aspects of the high maternal mortality. One, however, who was convinced that malnutrition was the prime cause was Lady Rhys Williams, the honorary secretary to the Joint Midwives' Council. Selecting the Rhondda because of its high maternal mortality rate, she conducted an experiment in which food supplements were distributed to expectant mothers. She claimed that, as a result, the maternal mortality rate (which included "associated deaths") fell from 11.29 in 1934 to 4.7 in 1935. It looked impressive. ${ }^{113}$ Unfortunately, this experiment was seriously flawed in two respects. First, obstetric services in the Rhondda were extensively improved just before food supplements were introduced: second, the food supplements were, to say the least, odd and inadequate, consisting of the distribution to each mother (on average) of $6 \times 4$ ozs. of Marmite, 6 x 6 ozs. of Brandex Extract of Beef, 6 x 8 ozs. of Ovaltine Egg and Milk Extract, less than one-fifth of a one-lb. tin of Dorella dried milk, and a free pint of milk a day in the last three months of pregnancy. There is no knowing how much of this was given to husbands or children, and even if it was none, "it seems probable", as Lady Williams admitted, "that the malnutrition of these women was not fully overcome". Packed and concentrated foodstuffs of this kind were then much in vogue, but their choice, says the author, was dictated by "the difficulties of administration and distribution of fresh foods". The paper is not convincing.

It is possible to criticize the medical profession and official bodies in the 1920s and 1930s for their relative neglect of social aspects of obstetric care. It is certainly true that most observers blamed poor clinical performance for the high mortality. Neither midwives nor general practitioners escaped blame, for not only were the general

\footnotetext{
${ }^{108}$ Milne Murray quoted in Williams (1904), op. cit., note 4 above, pp.35-36.

${ }^{109}$ Andrew Topping, 'Maternal mortality and public opinion', Public Hlth, 1936, 49: 342-349. "Many cases of maternal deaths were nothing short of murder, and he described several glaring examples" (p.349).

${ }^{110}$ Loc. cit., note 29 above, Q.378.

${ }^{111}$ The report by Dilys Jones in Campbell (1932), op. cit., note 4 above.

${ }^{112}$ Leading article, 'Maternal mortality in Wales', Med. Officer, 1937, 57: 215.

${ }^{113}$ Lady Williams, 'Malnutrition as a cause of maternal mortality', Public Hlth, 1936-37, 50: 11-19.
} 


\section{Deaths in childbed}

levels of obstetric care provided by each considered to be unacceptably low, but the absence of co-operation between the two, stemming from traditional competition and mutual hostility, was also perceived as an important cause of obstetric disasters.

In 1929 and the early 1930s, the Medical Research Council, at the request of the Ministry of Health, turned its attention to maternal mortality. In 1932, with a frankness and force in the preliminary draft which was muted in the final publication, the committee on maternal mortality listed the sins of omission and commission. ${ }^{114}$ The most important were thought to be, perfunctory attention to antiseptic techniques; failure to appreciate the importance of wearing masks; much unnecessary interference in normal labours; inadequate ante-natal care and selection of difficult cases for hospital delivery; midwives harassed by financial anxiety; poor co-operation between midwives and general practitioners in domiciliary midwifery; too few maternity beds; and poor obstetric training of midwives and doctors. Conspicuous by its absence was any suggestion that social and economic factors were important. In a remarkable letter on the hopelessness of persuading general practitioners to read a report on maternal mortality, let alone act on it, the director of the Stationery Office remarked: "The terrible thing about this latest Maternal Mortality Report is the revelation of the lives which might be saved, not by advanced technique, but by the simplest aseptic precautions that one would have expected medical men to observe on their own initiative". ${ }^{115}$ We share his sense of horror. Between 1930 and 1933, 10,660 mothers died in childbirth and at least forty per cent of these deaths were considered to have been potentially avoidable.

In 1979-82, the expected maternal deaths from the same number of deliveries would have been 295 .

But there was nothing new in most of these conclusions. Through the work of William Farr in the 1870s, Williams in 1904, and a number of authors up to 1932 , most of the Council's conclusions had already become established dogma, especially those concerning the failure to adopt antiseptic and aseptic techniques. These did not need to be applied with as much care as was needed in surgery to be effective in midwifery ${ }^{116}$ The statistics of the lying-in hospitals seemed to show how much could be achieved by antisepsis because, as Bonney observed in 1919, "Taking the conduct of labour in general, not much more than a bowl of antiseptic stands between the practice of today and the practice of the [eighteen] sixties". ${ }^{117}$ Whether it was the bowl of antiseptic, or the influence of the latter in effecting a new standard of cleanliness, is debatable. Probably it was both. In certain aspects of surgery a fall in

\footnotetext{
${ }^{114}$ Medical Research Council Archives, file 2060/2.

${ }^{115}$ This letter from Mr Scrogie of His Majesty's Stationery Office to Sir Walter Fletcher, Secretary of the Medical Research Council dated 13 October 1932, includes such gems as: "Excepting only the lack of interest shown by farmers in research for their benefit, there is nothing in the Stationery Office experience more disappointing than the lack of interest in the medical profession in the public health"; "In one [medical] man's house there is a stack of Lancets and British Medical Journals all unopened in their wrappers. He is 'much too busy'. He plays bridge five nights a week, belongs to every local club that can possibly attract business and lectures to girl guides on first-aid. Some girl guides are quite pretty. In his spare time he plays golf and reads the Sketch." Medical Research Council, London. Archives MRC 2060/2 G39/1195.

${ }^{116}$ Bonney, op. cit., note 4 above.

${ }^{111}$ Ibid., p.81.
} 


\section{Irvine Loudon}

the mortality in the 1880 s may well have been due to improved nutrition as much as antiseptis. ${ }^{118}$ In midwifery, however, antiseptic techniques seem to have been conspicuously successful in hospital and conspicuously absent outside. ${ }^{119}$ The root cause was poor training, which can be traced to the traditional hostility towards obstetrics of the teaching hospitals and the examiners, and, as far as midwives were concerned, the hostility of medical practitioners to the Midwives' Act. Donnison and Lewis have written admirable accounts of the obstructions placed in the way of obstetric education. ${ }^{120}$ The reports of the Select Committee on Medical Education in 1834, the Select Committee on the Medical Act Amendment Act in 1878-79, and the Select Committee on Midwives' Registration in 1892 provide a wealth of evidence on attitudes to midwifery, on recommendations for increasing the time spent on teaching midwifery and on the stubborn refusal of the examiners to agree to such changes. Even in 1932, when the Joint Education and Examination Committee of the General Medical Council reviewed the teaching of midwifery, the recommendation that students should spend six months in obstetrics and gynaecology and infant hygiene, and that this should include a two months' residency for practical experience in deliveries, was opposed by the teaching bodies, who proposed one month's residency and three months or less in all. ${ }^{121}$

It is not surprising that those concerned with the teaching of obstetrics, seeing what they believed was a low standard in general practice and, at the same time, faced with the opposition of their medical and surgical colleagues in teaching hospitals over the curriculum time for teaching obstetrics, believed the future lay in developing obstetrics as a hospital speciality with the ultimate elimination of the home delivery by the general practitioner.

One of the most uncompromising proponents of hospital delivery was Victor Bonney in 1919. In his opinion, "midwifery is a pure surgical art" since the baby was a "neoplasm" and "labour is a process accompanied by self-inflicting wounds and the puerperium a period of their healing". Hospitals, he said, were safe because: "Although the antiseptic measures employed in lying-in hospitals fall far short of those in use in general surgery, they have sufficed practically to abolish extrinsic infection[in spite of] the collection of a number of patients under one roof." There should be, he said, "large lying-in hospitals all over the country" and outside emergencies could be dealt with by a hospital team travelling by motor-car -the "flying-squad" principle. It was implied that, if general practitioners were to continue to practise obstetrics, it should be within the hospitals. ${ }^{122}$

The ignorance of the nineteenth-century midwives, the Sarah Gamps, was a byword amongst doctors, and since there was so much mutual hostility and most of the evidence about midwives comes from the medical profession, it is difficult to know how bad they were. Farr in 1841 admitted that some were excellent but continued that in many cases "the nurses and old women in attendance... have peculiar views of their own which they lose no opportunity of announcing and

\footnotetext{
${ }^{118}$ Hamilton, op. cit., note 69 above.

${ }^{119}$ See note 68 above.

${ }^{120}$ Donnison, op. cit., note 9 above; and Lewis, op. cit., note 54 above.

${ }^{121}$ Medical Research Council Archives, file 2060.

${ }^{122}$ Bonney, op. cit., note 4 above.
} 


\section{Deaths in childbed}

carrying into effect with the best intentions and the worst consequences". To Farr, the need for formal training of midwives was obvious. The time had passed when it could be argued that "midwives were born, not made". ${ }^{123}$

The Midwives' Act of 1902 was expected to lead to a rapid transformation in the standard of midwifery. What had not been anticipated, although it should have been, was the slowness of the transformation. In 1908, seventy-three per cent of midwives still practised without antiseptics and twelve per cent conformed to the drunken stereotype of Sarah Gamp. ${ }^{124}$ Because the Act allowed those who had been in active practice before 1902 to continue as "bona fide" midwives (like the "pre-1815" medical practitioners who continued to practise after the introduction of the Apothecaries' Act), it was not until the end of the 1920s that the majority of midwives ceased to be elderly and often unteachable local residents (some could not be taught to read a clinical thermometer) and became younger middle-class professionals. ${ }^{125}$ Not only was the "bona fide" group - some able and experienced, others not - active and numerous, especially in the country, but employment of the cheaper "handywomen" continued through the $1920 \mathrm{~s} .{ }^{128}$ For the first three decades of the twentieth century, therefore, the expected dramatic improvement in women employed as midwives occurred only slowly. The evidence that standards of care in midwifery before the Second World War were considered to be unacceptably and unnecessarily low is considerable. The evidence that this had a direct effect on the maternal mortality rate was largely circumstantial until the Rochdale experiment.

When Dr Andrew Topping went to Rochdale as Medical Officer of Health in 1930 , it had "the very unenviable distinction of having the highest [maternal] mortality rate in the country over a period of years". The average for the four years 1928-31 was "a fraction less than 9". By 1932, it had been reduced to 1.76; by 1933 to 2.87; a few unusual deaths brought the rate back up to 5.65 in 1934, but in 1935 it fell back to 1.75 . This dramatic fall was achieved by simple measures. Propaganda and the help of the press led to a high attendance rate at specially established ante-natal clinics; medical practitioners were made aware that "case reports for the previous years had shown... no ante-natal care... evidence of unnecessary and violent interference [whereby] shock and haemorrhage following a difficult labour was by far the commonest cause of death". Deliberate and effective publicity, the establishment of a genuinely effective and co-operating service of midwives, general practitioners, and a consultant recruited from Manchester, and the opening of a puerperal fever ward, seem to have brought a new optimism and to have been remarkably effective in lowering the mortality rate from childbirth. ${ }^{127}$ Although the paper was hailed as a breakthrough at the meeting where it was given, it was soon eclipsed by Colebrook and Kenny's paper on the use of sulphonamides in puerperal fever, published only five months later. ${ }^{128}$ Topping's paper is, however, historically important. It would be simple and tempting to attribute the undiminished maternal

\footnotetext{
${ }^{123}$ Registrar General's Report, 1841, pp.380, 1870.

${ }^{124}$ Lewis, op. cit., note 54 above, p.143.

${ }^{125}$ Ibid., p. 143.

${ }^{126}$ Ibid., pp.149-151.

${ }^{127}$ Topping, op. cit., note 109 above.

${ }^{128}$ Colebrook and Kenny, op. cit., note 8 above.
} 


\section{Irvine Loudon}

mortality up to 1935 to the absence of an effective agent for treating puerperal fever, and this view receives apparent confirmation by the steep decline in deaths after 1935. Yet, this was only part of the story. As many authors had suggested since the 1870 s, the continuing high maternal death rate was not so much due to some extraordinary and insurmountable factor but rather to the summation of a whole series of relatively slight and rather dull defects in education and sins of omission. Remedies were known and at hand but not applied. The Rochdale experiment provided vivid confirmation of this thesis. But it did more than that. When Oxley, Phillips, and Young reviewed the Rochdale experiment, they remarked:

It is significant that the analysis of the individual death records failed to reveal any evidence for the view that the high death rate of Rochdale could be attributed to factors arising out of the economic disabilities from which, as a highly industrialised community, this borough, in common with its neighbours, was naturally suffering during the years of the investigation. In other words, the investigation showed, in the majority of the cases, the existence of obstetrical factors which in many instances were capable, with considerable justification, of being regarded as preventable. ${ }^{129}$

\section{CONCLUSION}

It seems that the absence of any significant fall in the maternal mortality rate in Britain between the mid-nineteenth century (and possibly earlier) and 1935 was due to the absence of any significant improvement in the standard of domiciliary care by midwives and general practitioners during this period. Delivery at home by Denman or Granville in the early nineteenth century may have been as safe as delivery by the average midwife or general practitioner in Rochdale or Doncaster in 1930. The apparent absence of any relation between the maternal mortality rate and changing standards of living is surprising. While it suggests that social and economic factors were generally much less important than clinical factors, it would be a mistake to conclude that poverty and malnutrition can never affect maternal mortality. That would be an absurd proposition, and the explanation for the absence of any clear historical evidence of a connexion between malnutrition and maternal mortality within the period considered here may be due to a tacit assumption. That assumption is that the relationship is linear - that mild, moderate, and severe malnutrition respectively would produce a proportionate increase in mortality. The actual relationship may be quite different. It is possible that the physiological processes of childbirth are little affected by moderate or even quite severe degrees of malnutrition until, at some point of great severity, those processes break down and maternal mortality increases both suddenly and greatly. The imagined graph, instead of being a straight line, may be a very gentle slope turning suddenly into a steep ascent. Current studies from the Third World may throw light on this proposition. Indeed, answers might be sought on this and other problems of maternal mortality from a study of maternal mortality in other countries in the past two centuries. It was tempting to include such data during the preparation of this paper, but it became increasingly clear that comparative statistics would have no meaning unless they were presented within the context of all aspects of obstetric care in each country considered. In other words, it would be necessary to compare not only the statistics,

${ }^{129}$ W.H.F. Oxley, Miles H. Phillips, and James Young, 'Maternal mortality in Rochdale. An achievement in a black area', Br. med. J., 1935, i: 304-307. 


\section{Deaths in childbed}

but also the development of obstetric care, the relative amount of care provided at home or in hospital, the distribution between midwives and medical practitioners, the development of obstetric training and attitudes to obstetrics, and other factors which are known to affect mortality rates. This would have to be done for every country whose statistics were compared to those of Britain. While this would undoubtedly be an important contribution to the history of obstetric care, it was clearly impossible to contemplate within the confines of this paper.

\section{POSTSCRIPT}

This study terminated with the introduction of the sulphonamides. But a brief discussion of maternal mortality after 1936 has a bearing on the earlier period. The fall in maternal mortality from 1936 was, in the first few years, almost entirely due to the decrease in deaths from puerperal fever (fig.2). It can be attributed with confidence to the sulphonamides, and later the antibiotics. The fall in deaths from the "accidents of childbirth", which was largely unaffected by antibiotic treatment, started about 1939 and then followed a steep downward path in parallel with the fall in deaths from puerperal fever. Why? The suggested reasons for the overall reduction in mortality, are first the antibiotics and blood transfusion, and second, better clinical care, better education of medical students and midwives, greater co-operation between general practitioners and midwives and consultants, the increasing application of ante-natal care, and better nutrition with iron and vitamin supplements. All these changes were introduced on a very wide scale as a result of the wartime organization of food and maternity services. ${ }^{130}$ Once introduced, they were extended during the post-war period. Thus the changes which led to the dramatic fall in the deaths from "accidents of childbirth" were those which were conspicuous by their absence in the first third of the twentieth century. The reasons suggested for the undiminished mortality up to 1935 are consistent with those suggested for the subsequent sharp and sustained fall in childbirth deaths. The story as a whole can be seen to be consistent.

\section{ACKNOWLEDGEMENTS}

This work was undertaken during the tenure of a Wellcome Research Fellowship, and the author wishes to express his gratitude to the Wellcome Trust. Dr C. Redman, Obstetric Physician to the John Radcliffe Hospital in Oxford, kindly advised the author on current views on toxaemia. Charles Webster, Jonathan Barry, and David Hamilton of the Wellcome Unit for the History of Medicine in Oxford provided invaluable advice in the preparation of the manuscript, and Adrian Wilson gave kind permission to quote from his thesis on midwifery during the seventeenth and eighteenth centuries. Two secondary sources have been of very great value in understanding the complexities of medical men, midwives, and maternal care. They are Jean Donnison, Midwives and medical men, 1977, and Jane Lewis, The politics of motherhood: child and maternal welfare in England, 1900-1939, 1980, and the author would like to acknowledge their importance to his work. The author is grateful to Dr Alison Macfarlane for permission to reproduce figs. 3 and 4.

\footnotetext{
${ }^{130}$ For a review of the maternity services during the second world war, see On the state of the public health, $1939-45$, Ministry of Health, section IV, 'Maternity and child welfare.' For the effect of wartime measures and other factors in the reduction of maternal mortality see W. Gilliat, 'A discussion on maternal mortality' in A.W.Bourne and W.C.W.Nixon, (editors), XIIth British Congress of Obstetrics and Gynaecology, London, Austral Press, 1949.
} 